DIW BERLIN

Discussion

Papers

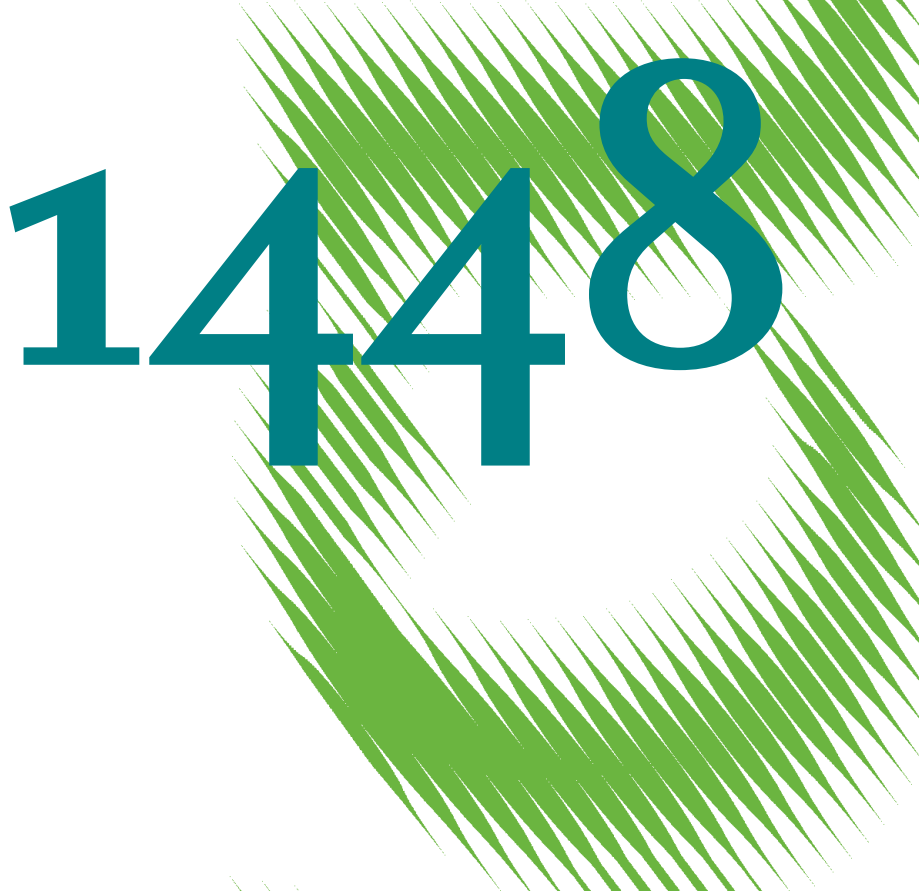

Monetary Policy, Bank Bailouts and the Sovereign-Bank Risk Nexus in the Euro Area 
Opinions expressed in this paper are those of the author(s) and do not necessarily reflect views of the institute.

IMPRESSUM

(C) DIW Berlin, 2015

DIW Berlin

German Institute for Economic Research

Mohrenstr. 58

10117 Berlin

Tel. +49 (30) $89789-0$

Fax +49 (30) $89789-200$

http://www.diw.de

ISSN electronic edition 1619-4535

Papers can be downloaded free of charge from the DIW Berlin website:

http://www.diw.de/discussionpapers

Discussion Papers of DIW Berlin are indexed in RePEc and SSRN:

http://ideas.repec.org/s/diw/diwwpp.html

http://www.ssrn.com/link/DIW-Berlin-German-Inst-Econ-Res.html 


\title{
Monetary policy, bank bailouts and the sovereign-bank risk nexus in the euro area ${ }^{1}$
}

\author{
Marcel Fratzscher \\ DIW Berlin, Humboldt-University Berlin and CEPR
}

\author{
Malte Rieth ${ }^{2}$ \\ DIW Berlin
}

05 February 2015

\begin{abstract}
The paper analyses the empirical relationship between bank risk and sovereign credit risk in the euro area. Using structural VAR with daily financial markets data for 2003-13, the analysis confirms two-way causality between shocks to sovereign risk and bank risk, with the former being overall more important in explaining bank risk, than vice versa. The paper focuses specifically on the impact of non-standard monetary policy measures by the European Central Bank and on the effects of bank bailout policies by national governments. Testing specific hypotheses formulated in the literature, we find that bank bailout policies have reduced solvency risk in the banking sector, but partly at the expense of raising the credit risk of sovereigns. By contrast, monetary policy was in most, but not all cases effective in lowering credit risk among both sovereigns and banks. Finally, we find spillover effects in particular from sovereigns in the euro area periphery to the core countries.
\end{abstract}

Keywords: $\quad$ Credit risk, banks, sovereigns, monetary policy, bank bailout, heteroscedasticity, spillovers.

JEL No.: $\quad$ E52, G10, E60.

\footnotetext{
${ }^{1}$ We are grateful to Helge Berger, Michael Burda, Fabio Canova, and Helmut Lütkepohl for their helpful comments. We also thank participants of seminars and conferences at HU Berlin, INFER/ IWH Halle Workshop 2014, ZEW Mannheim 2014, IAAE London 2014, Verein für Socialpolitik Hamburg 2014, and of an internal seminar for their helpful suggestions and discussions.

${ }^{2}$ M. Fratzscher (corresponding author): mfratzscher@diw.de. M. Rieth: mrieth@diw.de.
} 



\section{Introduction}

A key feature of the European crisis has been the ever closer link between sovereign risk and bank risk in the euro area. A major concern of policymakers has been the negative feedback loop, in which adverse shocks to banks led to an increase in sovereign risk, and a deterioration in sovereign risk, in turn, raised the solvency risk for banks. In fact, the correlation between credit default swap (CDS) spreads of banks and of sovereigns in the euro area rose from 0.1 to 0.8 between 2007 and 2013 (see Figure 1). The feedback loop has also been blamed for deepening the recession, thereby making an escape from the European crisis ever more difficult.

Policymakers have adopted two principle approaches of dealing with sovereign risk and bank risk during the 2008-09 global financial crisis and the subsequent European crisis. On the one hand, national governments implemented bank bailout and rescue policies, in particular by providing capital injections into ailing banks, by offering debt guarantees or by issuing deposit guarantees. On the other hand, monetary policy has played a central role, by providing liquidity to banks on a massive scale and by intervening in sovereign debt markets through outright purchases or by giving an implicit guarantee against a speculative run on sovereign debt of specific countries.

Have these policies been effective in reducing sovereign risk and bank risk and in breaking the negative feedback loop? The academic literature has analysed different channels through which these two policy approaches function. Concerning government policies for banks, there are two competing hypotheses about how such policies affect bank risk and sovereign risk (see Acharya et al., 2011, Allen et al., 2013, and Leonello, 2013). Guarantees and capital injections essentially imply a transfer of risk from banks to governments. If such policies are effective not only in preventing bank runs and ensuring the viability of the banks, reducing uncertainty and overall improving the outlook for the economy and the financial system, then these policies are expected to both lower the risk to the banking sector and to improve sovereign risk. However, if the bank bailout policies are large in magnitude and imply a major challenge to the sustainability of public debt, then such a transfer of risk may actually worsen sovereign risk, while improving the risk to banks. In an extreme case, a large deterioration in sovereign risk could become so dominant, that in fact it worsens both sovereign risk and bank risk together.

There is also an extensive literature focusing on the impact of non-standard monetary policies on financial markets during the global and European crisis. In particular, there is a growing literature on the effect of the Federal Reserve's quantitative easing (QE) policies (see, for example, Gagnon et al., 2011, or Fratzscher et al., 2012) and the effectiveness of the European Central Bank's (ECB) policies (see, for example, Manganelli, 2012, Eser and Schwaab, 2013). The controversy in this literature is to what extent these non-standard policies have been successful in reducing risk to banks and to sovereigns, but these risks have mostly been analysed in isolation, without 
studying the mutual feedback effects. Finally, there is also the possibility of a crosscountry transmission of shocks to sovereign or bank risk. Caporin et al. (2013), for instance, use a similar methodology to ours and find that the transmission within sovereign debt markets of the euro area has decreased with the onset of the European crisis.

The paper provides an empirical test of the effect of various bank rescue policies implemented by euro area countries and the various non-standard policies of the ECB since 2007 on the nexus between sovereign risk and bank risk. The primary interest is whether such policies have helped to break the nexus, or whether they have intensified it. The analysis starts with a more general analysis of the causality between bank risk shocks and sovereign risk shocks. The paper then goes into detail of this link, by investigating whether these two types of policies have functioned differently for healthy euro area countries versus crisis countries, and whether the impact has changed over time. Importantly, we also analyse whether there is evidence for crosscountry spillovers, that is, whether shocks to bank risk or sovereign risk in one country affect those in others.

We employ a set of structural vector auto regression (VAR) models which exploit the heteroscedasticity of financial market variables to identify shocks to bank risk, sovereign risk, and the other variables of the system. The baseline specification includes five endogenous variables: credit risk of the sovereign, banking, and nonfinancial sector, respectively, the term spread, and a stock market return index. We take as exogenous variables the non-standard monetary policy measures of the ECB as well as the announcement of major bank guarantees and of capital injections. In addition, the empirical model also includes implied volatility, a risk premium in the money market, and 12 macroeconomic news announcement shocks as controls.

In a multi-equation model with daily financial market data, it is hard to defend identification schemes based on exclusion, long-run, or sign restrictions. Instead, we identify contemporaneous causal effects through heteroscedasticity, following Sentana and Fiorentini (2001) and Rigobon (2003). The methodology exploits that periods of higher volatility contain additional information on the covariance between the endogenous variables. The advantage of this methodology is that identification is agnostic in that it does not impose structural relationships on the variables of the system.

The empirical analysis of the paper starts with the general link between sovereign risk and bank risk in the euro area for the period 2003-13. We find evidence for a two-way causality between these two types of risk. On average across euro area countries and over time, the benchmark specification suggests that an increase in sovereign CDS spreads by 100 basis points raises bank spreads by 38 basis points. Equally, a deterioration in bank risk by 100 basis points worsens sovereign risk by 28 basis points.

We also find evidence that the transmission channels function via risk to non-financial institutions, the term spread and equity markets. A decline in equity markets and a 
worsening in the solvency of non-financial firms both significantly raise the solvency risk of banks and sovereigns. Moreover, an exogenous increase in sovereign or bank risk both also lead to a deterioration in equity markets and the solvency of nonfinancial institutions. If one interprets the solvency of non-financial firms and the equity markets as reflecting the prospects of the real economy, then the implication of these findings is that the negative feedback loop between banks and sovereigns also extends to the real economy. In terms of economic significance, the forecast error variance decomposition suggests that indeed shocks to bank risk and to sovereign risk explain a sizable magnitude of the variance of each other and the real economy variables.

The empirical analysis also reveals a high degree of heterogeneity across countries in the euro area as well as over time. Before and during the global financial crisis, the impact of sovereign risk shocks on bank risk was generally insignificant or small in magnitude. The striking finding is that during the height of the global financial crisis in late 2008 and early 2009, a reduction of bank solvency risk was associated with higher sovereign risk. One possible interpretation of this finding is that expectations of bailouts and guarantees for banks may actually have raised the sovereign risk of vulnerable countries.

Since the start of the European crisis in 2010, we find an increase in the impact of sovereign risk on bank risk. Moreover, a shock that raises the solvency risk of banks during this period also increased sovereign risk. This finding confirms that the sovereign-bank feedback loop indeed intensified during the European crisis. As to the heterogeneity across countries, such a feedback loop hardly exists for core euro area countries, such as Austria, Germany and the Netherlands. By contrast, the loop intensified and reached high magnitudes for several crisis countries in the periphery. Later on, however, it largely ceased to exist in those crisis countries that where bailed out by IMF-EU programmes.

The empirical findings also suggest that there are strong cross-country spillovers of sovereign and bank risk. The largest spillovers stem from shocks to sovereign risk in the euro area periphery to sovereigns in the core, as well as from shocks to banks in the periphery to banks in the core. A positive shock to sovereign or bank CDS spreads by 100 basis points in the periphery raises solvency risk in the corresponding market of core euro area countries by 15 and 29 basis points, respectively. What is striking is that the impact of sovereign risk in the periphery on the core euro area countries has been larger than the causality running in the opposite direction. This is important since the core countries constitute the much larger share of the euro area, and its underlying sovereign debt market, than the periphery countries.

Finally, the empirical analysis tends to question whether government policies on banks and ECB non-standard monetary policy measures were effective in reducing the feedback loop between banks and sovereigns. For bank bailout policies, the estimates indicate that debt and deposit guarantees and capital injections into banks were moderately effective in reducing bank solvency risk. The important announcement by 
individual euro area countries to provide debt or deposit guarantees, or to recapitalize certain banks, lowered bank CDS spreads by 65 basis points on average.

By contrast, these policies had a much smaller impact on sovereign risk, and in some instances induce an increase in the solvency risk of national governments. This confirms the hypothesis that the second channel dominates. Bailout policies indeed lowered risk to the domestic banking sector somewhat, but this impact can come at the expense of a lower solvency of its sovereign.

As to monetary policy, ECB policies generally exerted a large and significant impact on sovereign risk and bank risk, but also on the real economy, as measured by stock returns and risk to non-financial firms. The empirical analysis reveals an interesting yet intuitive difference in the effects of monetary policy announcements as compared to their actual implementation. For instance, announcements about SMP were initially quite effective in lowering both sovereign and bank CDS spreads. However, the actual implementation, that is, the purchases over the different weeks, tended to increase bank risk and be ineffective in reducing sovereign risk. While it is hard to deal with the underlying endogeneity, the empirical estimates seem fairly robust to different specifications.

Also the effects of the other non-standard ECB policies show an intriguing picture. While the announcement of the 3-year LTROs was taken as a disappointment by financial markets, with sovereign and bank spreads actually increasing, the implementation was effective in reducing bank risk. OMT announcements also exerted a significant impact on financial markets, lowering sovereign CDS spreads on average by 56 basis points.

Overall, these findings suggest that both rescue policies of the banking system and monetary policy exerted a significant impact on sovereign and bank risk as well as on risks and prospects of the real economy. The empirical estimates also indicate that neither of the two policies was unanimously successful. Thus, this entails a note of caution to policymakers that policies that are intended to reduce risk can in fact lead to an intensification of the negative feedback loop between sovereigns and banks.

The paper is organised as follows. Section 2 provides a conceptual discussion of the feedback loop between sovereign risk and bank risk, and its relation to other asset classes. The subsequent section then discusses the empirical methodology and the data. Section 4 presents the empirical estimates for the transmission of bank shocks and sovereign risk shocks both domestically and internationally. The section offers a number of extensions and robustness tests. Section 5 then focuses on the effects of ECB non-standard monetary policy instruments and of bank bailout policies. The final section concludes. 


\section{Conceptual framework}

In this section, we derive priors for the empirical analysis. We first discuss transmission channels between bank risk and sovereign risk and other structural asset price shocks. Then, we outline potential effects of non-standard monetary policies on asset prices.

\subsection{The role of credit risk, the term spread, and stock returns}

A main hypothesis of the paper is that credit risk in the sovereign sector can affect credit risk in the banking sector, and vice versa. We start with transmission channels of bank risk shocks to sovereign risk. One is via credit supply. If banks' balance sheets deteriorate, say, as a result of unexpected losses, they reduce the supply of credit. This depresses investment and economic growth and hence lowers the tax base. Another channel is via bank bailout schemes. Before a bailout, banks often enjoy implicit support promises by their government. After a bailout, sovereigns explicitly guarantee for banks' liabilities. During those periods, rising bank risk increases (contingent) liabilities of sovereigns. Both channels imply that the effect of bank risk on sovereign risk is positive.

However, at the time when the bailout is actually occurs, the effect is ambiguous. It can be nil, if bailouts are fully effective in that they prevent bank runs beforehand and a risk transfer is not needed, as in the bank run literature following Diamond and Dybvig (1983). It can be positive, if good fundamentals of the economy, such as low government debt, render the bailout credible and reduce the solvency risk of the banking sector and hence of the sovereign sector, as in Leonello (2013). Finally, it can be negative, if the risk transfer undermines the solvency of the sovereign, as in Acharya et al. (2011).

Altogether, these considerations suggest that the sign of the effect of bank risk on sovereign risk can either be positive or negative. It depends on the types of shocks affecting the banking sector and their importance relative to other sector-specific shocks. If shocks mirror actual bailouts, we expect a negative effect. If other shocks dominate, we look for a positive sign. Finally, shocks can be amplified through mutual feedback and via third financial markets.

As to the reverse effect, if the probability of a sovereign default increases, say, due to an unanticipated widening in the deficit, the price of government bonds declines. This has two implications. First, banks incur losses on respective bond portfolios. Second, bank funding conditions deteriorate since they use government bonds as collateral in refinancing operations and the price of that collateral falls. Kallestrup et al. (2013), Angeloni and Wolff (2012), and De Bruyckere et al. (2012) provide evidence for these two channels in the euro area. In addition, there is a rating channel. Most rating agencies use sovereign ceilings according to which private entities cannot be rated higher than their sovereign. A rating downgrade of the sovereign then triggers a down rating of domestic banks. This, in turn, increases bank credit risk since many investors 
are legally constrained regarding the rating structure of their portfolio. Arezki et al. (2011) find evidence for this channel. All three channels imply a positive effect of sovereign risk on bank risk. Contrary, as outlined above, the bailout channel can entail a negative effect.

Regarding shocks to credit risk of the non-financial corporate sector, to the extent that they reflect negative surprises regarding its economic performance, they increase both bank risk and sovereign risk as the number of non-performing loans rises and the tax base declines. Indeed, Ejsing and Lemke (2011) show that a common credit risk factor accounts for large part of the variation of sovereign and bank CDS spreads. As concerns sovereign risk, Dieckmann and Plank (2012) and Gerlach and Schulz (2010) find that its first principal component explains more than three fourths of its variance. Regarding bank risk, Acharya et al. (2011) identify the iTraxx Europe CDS index as one important determinant. Guided by these findings, we include credit risk of the non-financial sector into our model. We expect it to be positively related to sovereign risk and bank risk.

The term spread consists of two components: expectations of future real rates and of inflation and sovereign credit risk. The first component reflects business cycle expectations. In recessions, public deficits widen and the number of non-performing loans grows. Hence, this component implies a negative co-movement between the term spread and solvency risk of sovereigns and banks. Conversely, the credit component reflects sovereign risk perception in the cash bond market and therefore implies a positive co-movement. Palladini and Portes (2011) suggest that the European sovereign CDS market moves ahead of its cash market while Fontana and Scheicher (2010) find that price discovery can run in both directions. Overall, we expect the business cycle component to dominate in normal times. But in times of economic and financial stress, we look for the credit risk component to prevail.

Equity markets reflect real growth expectations and risk appetite of investors. Both elements lower credit risk in the sovereign, banking, and non-financial sector, respectively. Longstaff et al. (2011) show that stock returns are one important determinant of sovereign CDS spreads. Altogether, we expect a negative relation between equity markets and credit risks.

\subsection{Non-standard monetary policy and credit risk}

In this subsection, we discuss the transmission channels of ECB policies to sovereign risk and bank risk. In particular, we consider LTROs with maturity 6-12 and 12-36 months, respectively, SMP, and OMTs. For LTROs and SMP, we distinguish between implementation and announcement effects. The latter work through anticipation of future monetary policy and economic conditions thereby affecting asset prices today. We group the measures into two categories. But generally, we expect them each to affect both risks in the same direction.

First, LTROs provide liquidity to banks. Their objective is to restore the functioning of impaired interbank markets. Lower funding risk of banks reduces the probability 
that liquidity turns into solvency risk. Hence, we expect LTROs to mainly reduce bank risk. In addition, if this improvement in bank risk translates into higher credit supply, output and tax revenues, it can also lower sovereign risk.

Second, SMP and OMTs support the depth and liquidity of secondary government bond markets through purchases of government securities. There are three main channels. The first two mainly affect sovereign risk while the third channel seems more relevant for banks. First, through a portfolio channel, ECB purchases lower the outstanding amount of debt securities. If assets are imperfect substitutes, bond prices should increase (see Tobin, 1958, or Vayanos and Vila, 2009). Second, large potential demand for bonds by the ECB lowers their liquidity premia (see De Pooter et al. 2012). Both channels, by lowering sovereign yields, reduce public financing costs and hence credit risk. A third channel works in the opposite direction via holdings of government bonds by private banks (see Buiter and Rahbari, 2012). These bonds, which are claims on sovereigns, can be crowded out and devalue if the ECB credibly postulates a senior creditor status in case of default. This mechanism suggests a positive effect of SMP purchases primarily on bank risk.

\section{Empirical methodology and data}

In this section, we present our baseline econometric model, the data as well as our identification strategy and the estimation procedure.

\subsection{Model specification and data}

Our baseline specification is a five-variable VAR which includes credit risk in the sovereign, banking, and non-financial sector, respectively, the term spread, and a stock market index. The endogenous variables depend on current and past values of themselves and of the other endogenous variables, and on exogenous variables:

$$
A y_{t}=\widetilde{c}+\widetilde{A}_{1} y_{t-1}+\cdots+\widetilde{A}_{p} y_{t-p}+\widetilde{\Gamma}_{0} x_{t}+\cdots+\widetilde{\Gamma}_{q} x_{t-q}+\varepsilon_{t},
$$

where $y_{t}$ and $x_{\mathrm{t}}$ is the vector of endogenous and exogenous variables, respectively, $\widetilde{c}$ is a vector of constants, $\widetilde{A}_{i}$ with $i=1, \ldots, p$ and $\widetilde{\Gamma}_{j}$ with $j=0, \ldots, q$ are coefficient matrices, and $\varepsilon_{t}$ a vector of structural shocks with diagonal variance matrix $\Sigma_{\varepsilon}=E\left(\varepsilon_{t} \varepsilon_{t}^{\prime}\right)$. The focus of the paper is on the matrices $A$ and $\widetilde{\Gamma}_{j}$. The off-diagonal elements of the impact matrix $A$ contain the contemporaneous effects of structural shocks on the endogenous variables, whereas the matrices $\widetilde{\Gamma}_{j}$ capture the effects of non-standard monetary policies and bank bailout announcements.

We collect daily data until 31 July 2013 for Austria, Belgium, France, Germany, Greece, Ireland, Italy, Netherlands, Portugal, and Spain. The longest available sample starts on 20 January 2004 for Austria. To measure credit risks, we use CDS spreads on senior unsecured debt, modified-modified restructuring, mid spread, with maturity of five years. It is the most liquid maturity segment. We collect CDS spreads of all ten 
sovereigns and of altogether 41 banks and 56 non-financial corporations of the respective countries. ${ }^{3} \mathrm{We}$ compute unweighted CDS averages for each sector at the euro area level and at the country level. We exclude Greece from euro area averages since the sovereign CDS series ends shortly after the sovereign default in 2011. For the term spread, we use the difference between the yield on government bonds with maturity of ten years and the three month interest rate on treasury bills. Concerning equity markets, we employ the Euro Stoxx 50 return index for the euro area level and benchmark local stock market return indices when looking at individual countries.

As regards the exogenous variables, we distinguish between ECB announcements regarding a specific programme, indicated by dummy variables, and their actual implementation, measured in billion euros. We outline the construction of the bailout announcements dummies in Section 5.2. Concerning control variables, we employ the VDax New, which measures option-implied volatility in the German stock market index Dax, to capture uncertainty in euro area financial markets. ${ }^{4}$ Moreover, we use the difference between the three month Euribor and the corresponding OIS spread to control for risk premia in the money market. Finally, to account for macroeconomic news shocks, we include the unexpected component of 12 economic indicators of the euro area. They are computed as the difference between expectations and actual realisations. For expectations, we use the mean of Bloomberg surveys, taken a few days prior to data releases. Our choice of indicators follows the construction of the Citi Economic Surprise Index which is widely observed by financial market participants. We provide a list of all variable definitions and sources in Appendix 3.

To account for non-stationarity of the data, we estimate the model in first differences of CDS spreads, the term spread, the VDax New and the interbank risk premium as they are already expressed in basis points. ${ }^{5}$ For stock indices, we employ log differences. We include two lags of the endogenous variables, mainly based on the Hannan and Quinn information criterion. All exogenous variables enter the model contemporaneously, except of monetary policy announcements. Here, we incorporate ten lags to account for information processing in financial markets.

\subsection{Identification through heteroscedasticity}

For estimation of the structural parameters, we pre-multiply equation (1) by $A^{-1}$ :

$$
y_{t}=A^{-1} \widetilde{c}+A^{-1} \widetilde{A}_{1} y_{t-1}+\cdots+A^{-1} \widetilde{A}_{p} y_{t-p}+A^{-1} \widetilde{\Gamma}_{0} x_{t}+\cdots+A^{-1} \widetilde{\Gamma}_{q} x_{t-q}+A^{-1} \varepsilon_{t} .
$$

\footnotetext{
${ }^{3}$ We combine CDS data from two sources, Thomson Reuters and Credit Market Analysis (CMA). Since CMA data end in 2010, we use growth rates of respective Reuters series for updating. The correlation between prices from both sources is mostly higher than 0.98 for an overlapping period 2007-2010.

${ }^{4}$ We use the VDax New instead of its analogue for the Euro Stoxx 50, namely, the VStoxx. The latter is only available since 2009 . The correlation between both indices is 0.92 .

${ }^{5}$ We perform augmented Dickey-Fuller and Phillips-Perron tests on the levels of the average sovereign and bank CDS spreads of the euro area. The tests do not reject the null hypothesis of a unit root, irrespective of whether we include a drift term.
} 
Next, we define $c \equiv A^{-1} \widetilde{c}, A_{i} \equiv A^{-1} \widetilde{A}_{i}, \Gamma_{j} \equiv A^{-1} \widetilde{\Gamma}_{j}$ and re-write (2) as

$$
y_{t}=c+A_{1} y_{t-1}+\cdots+A_{p} y_{t-p}+\Gamma_{0} x_{t}+\cdots+\Gamma_{q} x_{t-q}+u_{t},
$$

where $u_{\mathrm{t}}$ is a vector of reduced-form residuals. It is related to the structural shocks $\varepsilon_{t}$ through the impact matrix $A$ according to $u_{t}=A^{-1} \varepsilon_{t}$. The matrices $c, A_{i}$, and $\Gamma_{j}$ and the covariance matrix of reduced-form shocks $\Sigma_{u}$ of model (3) can be estimated consistently by ordinary least squares.

To recover the structural parameters from these estimates, we need to identify the impact matrix $A$. From equations (1)-(3), we know that the covariance matrices of reduced-form and structural shocks are related according to $\Sigma_{u}=A^{-1} \Sigma_{\varepsilon}\left(A^{-1}\right)^{\prime}$. However, in this system, the number of unknown parameters is larger than the number of independent equations. We need additional information to identify the unknown parameters on the RHS. For this purpose, we exploit the heteroscedasticity in the data. Consider a bivariate system without constants, lags, and exogenous variables for expositional purposes. Now, suppose that there are two regimes in the variances of the structural shocks: low and high volatility (indexed by superscripts $L$ and $H$, respectively).Then, the system is identified, here and in the general case, as we have six independent equations and six unknowns:

$$
\begin{aligned}
& \left(\begin{array}{cc}
\omega_{11}^{L} & \omega_{12}^{L} \\
\cdot & \omega_{22}^{L}
\end{array}\right)=\left(\begin{array}{cc}
1 & -a_{12} \\
-a_{21} & 1
\end{array}\right)^{-1}\left(\begin{array}{cc}
\sigma_{11}^{L} & 0 \\
0 & \sigma_{22}^{L}
\end{array}\right)\left(\begin{array}{cc}
1 & -a_{12} \\
-a_{21} & 1
\end{array}\right)^{-{ }^{\prime}}, \\
& \left(\begin{array}{cc}
\omega_{11}^{H} & \omega_{12}^{H} \\
\cdot & \omega_{22}^{H}
\end{array}\right)=\left(\begin{array}{cc}
1 & -a_{12} \\
-a_{21} & 1
\end{array}\right)^{-1}\left(\begin{array}{cc}
\sigma_{11}^{H} & 0 \\
0 & \sigma_{22}^{H}
\end{array}\right)\left(\begin{array}{cc}
1 & -a_{12} \\
-a_{21} & 1
\end{array}\right)^{-1^{\prime}} .
\end{aligned}
$$

Two assumptions are necessary for identification as can be seen from above. First, the structural shocks are uncorrelated, that is, the off-diagonal entries in $\Sigma_{\varepsilon}$ are zero. This assumption is standard in structural VAR modelling. Second, the slope parameters $a_{k l}$ are constant across regimes. This assumption is also common in ARCH or GARCH models. Finally, note that two regimes are enough for identification. With more regimes the model is overidentified.

Several alternative identification strategies exist. Exclusion restrictions are one prominent way. They postulate zeroes for specific entries in the impact matrix $A$, say, as a result of delayed responses of some endogenous variables to others. However, with daily financial markets data this seems too restrictive as financial markets are likely to respond to each other at much shorter frequencies. ${ }^{6}$

\footnotetext{
${ }^{6}$ This is also the reason why we do not use long run restrictions. The data do not contain much persistence.
} 
Sign restrictions on the parameters of $A$ are another route. They allow for simultaneous effects among all variables. However, as we outline in Section 2.1, neither theory nor empirical evidence gives unambiguous predictions for many of the contemporaneous effects. Signs depend on which shocks and transmission channels dominate. This ambiguity is particularly true for bank risk shocks and highlights the need to let the data decide. Put differently, it is precisely one of the main aims of the paper to determine the signs of the contemporaneous effects - together with their significance and magnitude.

Our parsimony in using restrictions comes at some costs, however. The system of simultaneous equations is only identified up to a rotation of the $A$-matrix, that is, up to a row permutation of the underlying economic model. To pin down the rotation which reflects this model, we need to impose one sign restriction on the $A$-matrix (for further details see Ehrmann et al., 2011). Hence, we assume that a positive shock to the equity market leads to a reduction in credit risk of the non-financial sector. We choose this assumption for several reasons. First, it seems economically fairly uncontroversial as, say, higher expected revenues and profits in the overall corporate sector are likely to lower credit risk of non-financial entities. Second, the constraint does not restrict the signs of the two main parameters of interest, that is, the bidirectional effects between sovereign risk and bank risk. Third, the constraint is mainly not binding in the estimation.

Before estimation, we need to determine the volatility regimes which contain the additional information necessary for identification. We use a narrative approach, following Rigobon (2003). For application of this methodology, the global financial and the European debt crisis provide a natural framework as they are characterised by strong and persistent increases in volatility in European financial markets. Specifically, we use media reports and previous studies to construct a time line of major economic and political events (see BIS, 2009, Acharya et al., 2011, Alter and Schüler, 2012, Mody and Sandri, 2012, Alter and Beyer, 2013). Based on the events, we divide the sample period into seven regimes. Figure 2 shows the time line and the regimes. It also contains the 200 days rolling standard deviations of the (differenced) euro area sovereign and bank CDS spreads, respectively. They increase in several steps which coincide well with our regimes. Appendix 1 provides a detailed account and analysis of the regimes. It also contains further stylised facts on the relation between sovereign risk and bank risk in individual member countries and groups thereof.

Finally, following Ehrmann et al. (2011), we estimate the parameters of $A$ by minimising the following matrix norm

$$
\left\|g^{\prime} g\right\|=\sqrt{\operatorname{tr}\left(g^{\prime} g\right)}=\sqrt{\operatorname{vec}(g)^{\prime} \operatorname{vec}(g)}, \text { whith } g=\sum_{i=1}^{7}\left[A \Sigma_{u, i} A^{\prime}-\Sigma_{\varepsilon, i}\right]
$$

where $\Sigma_{\varepsilon, i}$ is the variance of structural shocks and $\Sigma_{u, i}$ is the covariance matrix of estimated reduced-form shocks for regime $i=1, \ldots, 7$. We perform 200 bootstrap replications. In each replication, we use the regime-specific covariance matrices to 
generate new data from which we obtain estimates using the minimisation procedure. We calculate significance of the estimates by computing the share of estimates beyond zero.

\section{Propagation of credit risk in the euro area and member countries}

In this section, we present the results on the link between sovereign risk and bank risk and their relation to other asset prices. First, we analyse the euro area as one block before we look at single countries. Then, we split the sample into sub-periods. Finally, we explore the relationship between the euro area core and periphery. Throughout the section, we standardise the endogenous variables prior to estimation to facilitate a direct comparison of the economic effects across variables and countries and over time. $^{7}$

\subsection{Analysis of the euro area as a single entity}

We start by analysing the contemporaneous causal relationships among the endogenous variables at the euro area level. The upper part of Table 1 shows the estimated direct causal effects of a structural shock of one standard deviation (in columns) on the endogenous variables (in rows), keeping all other variables constant. It corresponds to the $A$ matrix of the structural model $A y_{t}=\ldots+\varepsilon_{t}$ of equation (1). We reverse the signs of the off-diagonal entries for ease of interpretation. The lower part of the table shows the overall causal effects in the initial period, contained in the $A^{-1}$ matrix. They take into account all contemporaneous propagation among all variables. We denote statistical significance at the $1 \%, 5 \%$, and $10 \%$ levels by $a, b, c$ below point estimates.

Regarding the relation between sovereign risk and bank risk, both the direct and the overall effects are positive in both directions. Moreover, they are statistically and economically significant. A one standard deviation increase in bank risk has a direct impact on sovereign risk of 0.14 standard deviations. The reverse effect is substantially stronger with a point estimate of 0.46 . Mutual feedback between sovereign risk, bank risk, and other asset prices amplifies the propagation of shocks. The overall effects are considerably larger than the direct effects. Bank shocks are magnified by up to $43 \%$ and sovereign shocks by up to $17 \%$. The overall effects imply that, in basis points, a shock of 100 to bank risk pushes up sovereign spreads by 28. Vice versa, the effect is 38 basis points. Finally, given that the effect of bank risk on sovereign risk is positive, we infer that, over the entire sample, bailout shocks play a secondary role in driving bank risk. Other sector-specific shocks, which imply a positive effect, dominate.

\footnotetext{
7 In addition, the standardisation simplifies the computational implementation of the estimation procedure since the estimated impact effects are of similar order of magnitude.
} 
Concerning shocks to other asset prices, they significantly affect the solvency of the sovereign and the banking sector. Focusing on the overall effects, non-financial risk shocks increase sovereign and bank risk by 0.07 and 0.29 standard deviations, respectively. The effects of stock market shocks are of similar (absolute) size. ${ }^{8}$ In the reverse direction, shocks to sovereign and bank risk increase non-financial risk and the term spread and they reduce stock returns. Altogether, coefficient signs correspond well to our priors and interpretation of shocks.

To understand what drives the positive correlation between sovereign risk and bank risk shown in Figure 1 and reflected in their positive bidirectional effects, we perform the following counterfactual exercise. First, we compute the historical decomposition of the sovereign risk and bank risk variable, respectively, which yield the contribution of each structural shock to the daily evolution of both variables. Then, we calculate the evolution of both variables under the assumption that only one particular shock materialised and compute the (counterfactual) correlation between both variables over rolling windows of 200 days. Finally, we compare the shock implied correlations to the actual correlation to assess the importance of each shock for the evolution of the latter. $^{9}$

Figure 3 contains the results. The shock implied correlations can be grouped in two. The first group accounts for the dynamics and overall level of the actual correlation (see upper panel). It contains the correlations implied by shocks to bank risk, to nonfinancial risk, and to stock returns, respectively. Bank risk shocks explain a large part of the higher frequency movements of the actual correlation. Non-financial risk shocks and stock market shocks account for its level. Altogether, however, shocks in the first group alone cannot explain the marked shift in the level of the actual correlation.

Instead, shocks in the second group can explain it (see lower panel). The group contains the correlation implied by sovereign shocks and by own shocks. Own shocks refer to sovereign risk being driven by sovereign shocks only and bank risk by bank shocks only. They drive up the implied correlation by about $0.5-1.0$ over the sample period.

To understand the low level of the correlation implied by own shocks before, approximately, 2010, we consider two shock scenarios. First, the implied correlation is low if mainly bank shocks occur. This scenario corresponds well to the period where the US subprime crisis spilled over the Atlantic and severely stressed European interbank markets, while the sovereign sector still stood relatively sheltered apart. In the second scenario, the implied correlation is low if both shocks to sovereign risk and bank risk occur but if they tend to go in opposite directions. This scenario reflects the

\footnotetext{
${ }^{8}$ In case of the term spread the results are less conclusive. The ambiguity seems to reflect the offsetting effects of its components.

${ }^{9}$ We neglect the correlation implied by term spread shocks since they are insignificant in explaining sovereign and bank risk (see lower part of Table 2).
} 
period after the collapse of Lehman Brothers when most euro area sovereigns implemented major bailout packages for their domestic banking sectors. These bailouts came as negative shocks to bank risk and tended to push up sovereign risk.

To understand the high level of the correlation implied by own shocks after 2010, we consider a third scenario. Here, sovereign risk and bank risk are positively correlated if shocks to both variables occur and if they move in the same direction. This scenario seems particularly relevant for the period since 2010, when the European debt crisis gathered pace. One illustrative example for positively related own shocks is the introduction of the European Financial Stability Facility (EFSF) on 10 May 2010 which accounts for the pronounced surge that can be seen in most correlations on that day.

Finally, these scenarios are mirrored in the evolution of the correlation implied by sovereign shocks. It increases from 0.5 to 0.9 as the relative importance of sovereign shocks grows over the sample period. In contrast, the importance of bank shocks remains largely at the same level (see upper panel).

\subsection{Overall effects in individual euro area member countries}

As suggested by Figure A1, which shows rolling correlations between bank risk and sovereign risk in individual member countries, there is considerable heterogeneity in the relationship between sector risks across countries. In this subsection, we therefore estimate the model using country-specific endogenous variables to detect commonalities and differences across countries and vis-à-vis the euro area en bloc.

Table 2 contains the results. We focus on the bidirectional overall effects between sovereign risk and bank risk. ${ }^{10}$ The first column in the upper part of the table repeats the results for the euro area for comparison. In Austria, Belgium, Germany, Spain, and France there is a significant positive effects in both directions. For the first three countries, the bidirectional effects are smaller than for the euro area, whereas they are of similar magnitude in Spain and France. As with the euro area, the effect from sovereign risk on bank risk tends to be larger than vice versa. There is a second group of countries with no or unidirectional effects. In Greece and Italy, there is an effect from sovereign risk on bank risk, which accords well with the perception that credit risks in these countries originated mainly in the sovereign sector, while in the Netherlands only the reverse effect is significantly positive.

Two underlying features seem relevant for understanding the grouping of countries. First, broadly speaking, the larger was the bailout package for the banking sector, the

\footnotetext{
${ }^{10}$ By and large, the signs of the other coefficients in the $A$ and $A^{-1}$ matrices are as expected. For example, credit risks across all three sectors tend to be positively related, while the effects between the term spread and other asset prices vary across country. In periphery countries, the credit component mostly dominates, inducing a positive relation with credit markets and a negative with the equity market, whereas in many core countries the business cycle part prevails, implying opposite comovements.
} 
tighter is the link between both sectors. In the first group, bank support indeed ranged from $18 \%$ in France to $47 \%$ in Belgium in terms of GDP (see Stolz and Wedow, 2010). In the second group, Italy, for example, provided only 4\%. An exception to the 'rule' is Netherlands with large bank support of $52 \%$ but only a small unidirectional effect. Yet, for Ireland, Greece, and Portugal there seems to be a second mechanism that breaks this rule. All three sovereigns were bailed out. As a consequence, bank risk on their balance sheets was, at least partly, forwarded to other sovereigns, breaking the link between domestic sectors - even in Ireland with state support for the domestic banking sector of $319 \%$.

Overall, the grouping coincides well with the widely used classification of euro area countries into core and periphery. We investigate this issue further below. Moreover, the findings square well with previous studies and narrative evidence on the severity of banking and sovereign debt problems in individual member states (see, for example, Alter and Schüler, 2012, Mody and Sandri, 2012).

\subsection{Overall effects in sub-samples}

In this subsection, we assess the relation between sovereign risk and bank risk in recursive sub-samples to see whether it changed over time, in particular, surrounding bailout periods. To this end, we hold the starting point fixed and let the estimation window grow in steps of the pre-defined regimes. Accordingly, the first window consists of regimes 1-2, the second of regimes 1-3, and so on. ${ }^{11}$ We standardise the endogenous variables over each window. Estimation of rolling windows did not yield meaningful results. This probably reflects the importance of the marked volatility changes between regimes 1 and 4 for identification, whereas later on changes in volatility are smaller, and the need for having sufficient observations in each subsample.

Figure 4 contains the results. Again, we report only the overall effects between sovereign risk and bank risk. The upper left graph in the upper panel shows the results for the euro area. In the first window, there is no significant effect in either direction. Subsequently, however, there is a significant positive effect of sovereign risk on bank risk in the range of 0.45 to 0.59 (solid line). The reverse effect (dashed line) is significantly negative in windows 2 and 3 at -0.04 and -0.18 , respectively. It turns significantly positive afterward. We interpret the negative effect as mirroring bailouts. They came as a series of bank risk shocks that drove bank risk and sovereign risk in opposite directions. According to the point estimates, a bailout shock that lowers bank spreads by 100 basis point leads to an increase in sovereign spreads by 12 basis points on average. From window 3 onwards, actual bailouts cease to occur and other transmission channels, such as the post-bailout channel, gain importance, which imply a positive effect. Acharya et al. (2011), Stanga (2011), and Dieckmann and Plank

\footnotetext{
${ }^{11}$ Due to data limitations, for Ireland the first window consists of regimes 2-3 and for Greece the last window only contains regimes 1-6.
} 
(2012) find a similar, sign-changing correlation pattern between bank and sovereign spreads during and after bailout periods. ${ }^{12}$

Looking at single countries, we find a similar sign pattern for the bidirectional effects in most core countries (see upper panel). In periphery countries, there is no clear pattern (lower panel). The grouping of countries corresponds largely to that of the previous subsection. It supports the interpretation that the link between the two sectors, which exists in many core countries, reflects credit risk transfers. The results for Greece and Ireland also strengthen the interpretation of what breaks the link. While the transmission from banks to sovereigns is negative in windows 2 (and 3), echoing bank bailouts, it turns insignificant afterwards, reflecting risk transfers to other sovereigns.

Finally, we define contagion as a significant increase of asset market interdependence after a shock or trigger event, following Forbes and Rigobon (2002) and Constâncio (2012). Specifically, and applied to the relationship between sovereign risk and bank risk, we define as contagion the emergence of a statistically and economically significant effect in either direction where no such effect existed beforehand. According to this definition, there was contagion between sovereign risk and bank risk since 2008 both at the euro area level and in nearly all analysed member countries.

\subsection{Credit risk spillovers between euro area core and periphery}

Based on the previous results, we now return to the euro area specification and split the sovereign and bank variable each into core (CO) and periphery (PE) to investigate cross-country spillovers. ${ }^{13}$ Table 3 shows the overall effects. Concerning the transmission of credit risk shocks, the cross-effects among all credit sectors are highly statistically and economically significant and have the expected positive signs. To rank the strength of the transmission we sum columnwise over the top four rows of the table. The largest effects on other sovereigns and banks has periphery sovereign risk (2.65), followed by core sovereign risk (2.19), periphery bank risk (1.84), and core bank risk (1.56).

For the sovereign-bank relation within country groups, we find significant bidirectional effects both within the core and periphery. The magnitude of effects is

\footnotetext{
${ }^{12}$ A somewhat puzzling result is that in many cases the effect of bank risk on sovereign risk is still negative in window 3 inasmuch as bailout announcements took place mostly during window 2 . We have three tentative explanations. First, as a statistical phenomenon, the estimates of window 3 are dominated by the sample of window 2. Second, the bailout effects were still present in window 3 as either new information became available regarding the actual bailout implementation or information processing in financial markets was still going on. Third, the sovereign bailouts of Greece, Ireland, and Portugal, which all occurred only in window 3, reduced core bank risk and increased core sovereign risk as they transferred periphery sovereign risk on the balances of core banks to core sovereigns.

${ }^{13}$ We classify as core Austria, Belgium, France, Germany, and Netherlands and as periphery Ireland, Italy, Portugal, and Spain.
} 
similar to the euro area specification with stronger effects of sovereign shocks on banks than vice versa. The reverse effect is larger in core countries than in the periphery, where it is barely significant. Again, banking risk seems relatively more important in core countries, whereas in periphery countries sovereign risk plays a relatively larger role.

Regarding spillovers across country groups, we observe strong links both within and across sectors. Within sectors, spillovers are larger from the periphery to the core than the other way around. This is surprising given the relative sizes of the corresponding economies and debt markets. Across sectors, the effect of sovereign on bank risk is stronger than vice versa, similar to the results within each country group.

To further investigate the economic significance of the structural shocks, we compute one day ahead forecast error variance decompositions. They yield the percentage that each shock type contributes to the variance of an endogenous variable. Given that shock variances are regime specific, we calculate the weighted average variance decomposition over all regimes, using the number of observations per regime as weights.

Table 4 contains the results. Altogether, they echo the overall effects. First, sovereign risk is more important in explaining bank risk than vice versa. Combined sovereign risks explain $24 \%$ and $11 \%$ of the variability in periphery and core bank risk, respectively. In contrast, combined bank risk shocks contribute only $3 \%$ and $4 \%$ to sovereign risk variability. Second, the dominance of the sovereign sector is particularly strong in the periphery where it contributes $16 \%$ to the bank risk variance. Third, periphery shocks contribute more to the variance of core variables than vice versa. Fourth, partly implied by the first two observations, other than own shocks play an important role for bank risk variability, whereas for sovereign risk variability their contributions are smaller. Regarding non-financial risk shocks, they explain relatively large shares of bank risk but have only a limited impact on sovereign risk. Stock market shocks contribute between $3 \%$ and $8 \%$ to the variability in credit risks. In Appendix 2, we provide a detailed analysis and interpretation of the estimated structural shocks.

Finally, we investigate whether there is evidence for a flight-to-safety within the euro area. In particular, we explore whether adverse shocks to euro area asset markets trigger a flight of investors to the safe haven of German sovereign bonds. To this end, we employ the German CDS spreads to measure core sovereign risk and we replace the euro area term spread by the ten year Bund yield. Table 5 shows the overall effects.

We indeed find evidence for this phenomenon in the euro area. Except of core banks, all credit risk shocks entail significant negative effects on Bund yields. Non-financial risk shocks have the largest negative impact, followed by shocks to periphery sovereign risk. Shocks to periphery bank risk are less influential. Interestingly, even shocks to German sovereign risk trigger flows to the presumably safe haven of Bunds. Reversely, Bund yield shocks significantly lower both sovereign risk and bank risk in 
the periphery which indicates that in Bund yields the business cycle component dominates.

Comparing the first columns of Tables 3 and 5, we see that the effect of German sovereign risk on the other variables is always smaller (in absolute value) than that of (average) core sovereign risk. Moreover, shocks to periphery sovereign risk do not impact on German sovereign risk. This stands in contrast to their effect on core sovereign risk which is highly statistically and economically significant. Overall, this suggests that the credit market perception of Germany is different to that of the average core sovereign.

\section{Effects of monetary policy and bank bailout announcements}

In this section, we first analyse the effects of specific ECB measures on asset prices in the euro area, and in particular on the solvency risk of sovereigns and banks. Then, we estimate the announcement effects of specific bank bailout schemes on those risks. Throughout, the endogenous variables are in basis and in percentage points, respectively.

\section{$5.1 \quad$ Non-standard monetary policy, credit risks, and other asset prices}

In this subsection, we first analyse the effects of non-standard monetary policies on euro area credit risk and other asset prices. Then, we look at individual countries. Here, we focus on the effects on sovereign risk and bank risk.

\subsubsection{Non-standard monetary policy and euro area asset prices}

In this subsection, we analyse the effects of specific non-standard monetary policy measures on sovereign risk and bank risk at the euro area level. To this end, we return to the five-variable VAR specification for the euro area en bloc. We extract the estimated coefficients on the exogenous monetary policy variables and compute additional statistics. They are shown in Table 6 , where the endogenous variables are ordered in columns. The upper part reports the implementation effects. Specifically, it contains the point estimates and the cumulative effects. The latter are the product of the point estimate, if significant, and the total volume of the respective programme. The lower part of the table contains the announcement effects which are the sum of the contemporaneous effect and its first ten lags. The p-value refers to the F-test of their joint significance.

As to the results, all monetary policy measures each drive sovereign risk and bank risk in the same direction. This commonality holds both for implementation and announcement effects. It underscores the strong interdependence between both sectors.

Turning to the announcement effects first, they are largely in line with our theoretical considerations. Announcements regarding 6-12 months LTROs, SMP, and OMTs, 
respectively, significantly reduce credit risks. There are, however, noteworthy differences in the magnitude of effects both across measures and sectors. SMP and OMTs announcements are most effective. The former reduce sovereign and bank CDS spreads by 52 and 40 basis points, respectively. Similarly, the latter lower them by 56 and 34 basis points, respectively. The stronger effect on sovereign spreads is consistent with the primary goal of both programmes of reducing tensions in public debt markets.

Regarding LTROs with maturity of 6-12 and 36 months, respectively, the results are surprising. While, as expected, announcements regarding the former reduce sovereign spreads by 6 basis points and bank spreads by 1 basis point, the announcement of the latter increases them by 40 and 26 basis points, respectively. There are two complementary explanations for this effect. First, market participants were disappointed as they expected the announcement of a reactivation of SMP during the ECB press conference on that day. Second, they underestimated the volume that was going to be allotted within this scheme. Ultimately, it was more than one trillion euro.

Next, turning to the implementation effects, we find the expected negative effects of LTROs on bank risk. Moreover, they are highly statistically significant. For 6-12 months LTROs, the allotment of one billion euro lowers bank CDS spreads by 0.01 basis points. Given that overall 979 billion euros were tendered within this scheme, the cumulative effect is -7.8 basis points. The implementation effect of 3-year LTROs is substantially stronger at -0.05 basis points per billion. The cumulative effect (of a total volume of 1,020 billion euros) is -47.9 . Netting it with the positive announcement effect yields an overall effect of -21.9 basis points.

In contrast, SMP purchases significantly increase bank spreads - by approximately 1 basis point per billion. We interpret the positive effect as mirroring the crowding out of privately held claims. Given that the ECB bought government bonds worth 218 billion euro, the cumulative effect is 209 basis points. Subtracting the effects of two announcements, the programme's overall effect is 129 basis points. ${ }^{14}$

Altogether, OMT announcements were most successful in reducing credit risks in the sovereign-bank nexus. One of the programme's most appealing features seems to be that it was never activated or put to a test by markets. In contrast, while SMP announcements had quantitatively similar effects, these were more than off-set by shortcomings regarding its implementation. Finally, specifically targeted at banks, indeed both considered types of LTROs effectively reduced bank credit risk.

\footnotetext{
${ }^{14}$ When interpreting announcement and implementation effects of SMP separately, one needs to keep two things in mind however. The first announcement regarding SMP occurred on the same day as the announcement of the establishment of the EFSF. Moreover, both announcements regarding SMP fall within the respectively same week when the ECB actually started buying sovereign bonds.
} 


\subsubsection{Non-standard monetary policy effects in member countries}

Next, we explore the effects of monetary policy at the country level. We first assess the effects on sovereign CDS spreads, before we turn to bank CDS spreads. Generally, we expect stronger effects in the periphery. Table 7 shows the effects on sovereign spreads. They are based on the sovereign risk equation of the corresponding country VAR. For comparison, the first column repeats the results for the euro area. The countries are grouped into core first and then periphery.

As to the announcement effects first, the country level results largely mirror those for the euro area. While the announcement effect of 3-year LTROs is positive, it is negative for 6-12 months LTROs, SMP, and OMTs, respectively. For the latter two programmes, the effect is highly statistically significant in all countries. Moreover and intuitively, it is considerably stronger in the periphery. For SMP it spans from -80 basis points in Spain to -2140 in Greece. For OMTs the range is -80 in Ireland to 124 in Portugal.

Turning to the implementation effects next, an interesting difference emerges between 6-12 months and 3-year LTROs. While the former significantly lower sovereign spreads in most core countries and in Ireland, the latter have a negative effect only in Spain and Italy. This pattern corresponds well to the timing of each liquidity scheme. The shorter dated LTROs were mainly implemented in 2008-2010 when banks in core countries and Ireland were hit hardest by the global financial crisis. One explanation for the negative effect is that the extra liquidity reduced risks in their banking sectors and thereby also potential spillovers to domestic sovereigns. On the other hand, the longer dated LTROs were implemented at the turn of the year 2011/2012 when the European debt crises escalated - precisely in Italy and Spain. The strong impact on these two countries likely reflects the so-called 'Sarkozy carry trade' according to which banks, in particular in Italy and Spain, used the liquidity provision to increase their exposure to the domestic sovereign (see, for example, Merler and Pisani-Ferry, 2012).

Table 8 shows the effects on bank spreads. The implementation of LTROs with maturity 6-12 months mainly reduces bank risk in core countries. Regarding 3-year LTROs, the implementation effect is significantly negative in almost all countries. The impact tends to be stronger in the periphery where it lowers Portuguese, Spanish, and Italian bank spreads by $-138,-67$, and -53 basis points, respectively. Moreover, in all cases where both the implementation and the announcement effect are statistically significant, the former dominates such that the overall effect of 3-year LTROs is always negative. Contrary, purchases within SMP tend to increase credit risk in Germany, Austria, Italy, and Greece. In addition, the cumulative implementation effect always outweighs the cumulative announcement effect. Finally, OMTs announcements have the strongest effect in Italy and Spain. Here, bank spreads decrease by 71 and 55 basis points, respectively. 


\subsection{Effects of bank bailout announcements on sovereign risk and bank risk}

In this subsection, we analyse the effects of specific bank bailout announcements on sovereign risk and bank risk in the euro area. Specifically, we consider announcements of three types of bailouts by national federal governments, following (CGFS \& BIS, 2010): (a) debt guarantees, (b) deposit guarantees, and (c) capital injections. The announcement dates correspond to the very first official announcement of the bailout type. This does not preclude that at latter stages new information was released regarding its timing, scale, and scope. We use dummy variables at the country level to indicate the announcement dates. Then, we average over countries to assess the effects at the euro area level. An analysis at the member state level is prohibited by the fact that most member states announced more than one bailout scheme on the same day and the composition of jointly announced bailout types differs across countries.

We use dummy variables instead of measures that aim at capturing the magnitude of the announced programmes because such measures would be difficult to compare across countries. In addition, several announcements are relatively general without specifying the overall implied amounts. Further, we neglect the implementation of bailouts as the details vary substantially across countries, complicating a meaningful aggregation.

We resort to the five-variable VAR specification for the euro area and include, one at a time, the announcement variables as additional exogenous variable. Including all announcement types jointly did not yield meaningful results due to problems of multicollinearity. Therefore, to cleanly trace out the specific effects, we use 20 lags. The lag length also accounts for the fact that scale and scope of the announced measures were relatively unprecedented in the euro area at that time and information processing and learning by market participants probably took several weeks.

The bottom of Table 9 shows the cumulative effects of the announcements. Columns (1)-(3) contain the results for the sovereign risk equation, columns (4)-(6) for the bank risk equation. The upper part of the table shows the effects of monetary policy for comparison. They are largely unaffected by the inclusion of the bailout announcements.

All bailout announcements are highly statistically significant. While the announcement of debt guarantees and capital injections slightly increases sovereign CDS spreads by 1 and 4 basis points, respectively, the announcement of deposit guarantees has a negative effect of 31 basis points. This negative effect might reflect the broader nature of this measure which targets not only the banking sector but also partly shields the household sector and its savings decisions from negative spillovers.

In contrast, the effect on bank spreads is always negative. Moreover, it is always larger in absolute value than the effect on sovereign spreads. The announcement effect of deposit guarantees and capital injections, respectively, is similar in magnitude at 
about -75 basis points. The effect of debt guarantees is somewhat smaller, but still sizeable at -46 .

Overall, the results confirm the presumption that the announcements of bank bailouts reduced solvency risks in banking sector, at least for a certain period of time. However, the results for sovereign risk are ambiguous. In some instances bailout announcements have increased sovereign risk while in others they lowered it. As outlined in Section 2.1, the ambiguity underscores the need for an agnostic identification approach.

\section{Conclusions}

The paper finds evidence in favour of a close and a much higher bank-sovereign nexus during the European financial crisis than compared to the pre-2008 tranquil period. Using a structural VAR that exploits the heteroscedasticity of the underlying daily series of financial market data, the analysis shows that sovereign risk shocks had an important and dominant impact on bank risk in the euro area. While also shocks to bank risk had an adverse impact on sovereign risk within the own country, sovereign risk overall appears to have been the more important driver of the bank-sovereign nexus.

This link has intensified significantly over time, with it being much weaker within Europe during the global financial crisis than the subsequent European crisis. We find evidence for larger spillovers of sovereign risk and bank risk in the euro area periphery to the euro area core than vice versa, despite the latter being much larger in magnitude. We also present suggestive evidence for a flight-to-safety phenomenon towards Germany.

The core analysis of the paper focuses on whether and how bank bailout policies and monetary policy by the ECB have affected this bank-sovereign nexus. Bank bailout policies, such as capital injections into ailing banks and debt and deposit guarantees, exerted a significant impact on both sovereign risk and bank risk. Importantly, we find evidence that in some instances such bailout policies actually raised sovereign risk. As to monetary policy, our results show that OMTs were most successful, insofar as they reduced credit risks in both sectors. In contrast and surprisingly, the actual implementation of SMP tended to increase solvency risk of banks. The 3-year LTROs effectively reduced bank risk while their effect on sovereign risk was at best ambiguous.

Overall, these findings suggest that both rescue policies of the banking system and monetary policy exerted a significant impact on sovereign and bank risk as well as on risks and prospects of the real economy. The empirical estimates also indicate that neither of the two policies was unanimously effective. Thus, this entails a note of caution to policymakers that policies that are intended to reduce risk can in fact lead to an intensification of the negative feedback loop between sovereigns and banks. 


\section{Bibliography}

Acharya, V., Drechsler, I., \& Schnabl, P. (2011). A Pyrrhic Victory? - Bank Bailouts and Sovereign Credit Risk. NBER Working Paper No. 17136, p. Working Paper 17136.

Allen, F., Carletti, E., Goldstein, I., \& Leonello, A. (2013). Government Guarantees and Financial Stability. mimemo.

Alter, A., \& Beyer, A. (2013, February). The Dynamics of Spillover Effects during the European Sovereign Debt Turmoil. European Central Bank (ECB) working paper series, No. 1558.

Alter, A., \& Schüler, Y. $(2012,12)$. Credit spread interdependencies of European states and banks during the financial crisis. Journal of Banking \& Finance, pp. 3444-3468.

Angeloni, C., \& Wolff, G. (2012). Are banks affected by their holdings of government debt? Bruegel Working Papers, No. 717.

Arezki, R., Candelon, B., \& Sy, A. (2011). Sovereign Rating News and Financial Markets Spillovers: Evidence from the European Debt Crisis. IMF Working Paper 68.

BIS. (2009). BIS, 79th Annual Report . Basel: Bank for International Settlement.

Buiter, W., \& Rahbari, E. (2012). The ECB as Lender of Last Resort for Sovereigns in the Euro Area. CEPR Discussion Paper 8974.

Caporin, M., Pelizzon, L., Ravazzolo, F., \& Rigobon, R. (2013, January). Measuring Sovereign Contagion in Europe. NBER Working Paper 18741.

CGFS, \& BIS. (2010, October 27). Financial sector rescue plan database, maintained by the BIS, under the auspices of the Committee on the Global Financial System (CGFS).

Constâncio, V. (2012). Contagion and the European debt crisis. Banque de France, Financial Stability Review No. 16, pp. 109-121.

De Bruyckere, V., Gerhardt, M., Schepens, G., \& Vennet, R. (2012). Bank/Sovereign Risk Spillovers in the European Debt Crisis. Working Paper Research 232, National Bank of Belgium.

De Pooter, M., Martin, R., \& Pruitt, M. (2012). The Effects of Official Bond Market Intervention in Europe. Federal Reserve Board of Governors.

Diamond, D. W., \& Dybvig, P. H. (1983, 91). Bank runs, deposit insurance, and liquidity. Journal of Political Economy, pp. 401-419.

Dieckmann, S., \& Plank, T. (2012). Default Risk of Advanced Economies: An Empirical Analysis of Credit Default Swaps during the Financial Crisis. Review of Finance, pp. 903-934.

Ehrmann, M., Fratzscher, M., \& Rigobon, R. (2011). Stocks, bonds, money markets and exchange rates: measuring international financial transmission. Journal of Applied Econometrics, Volume 26, Issue 6, pp. 948-974.

Ejsing, J., \& Lemke, W. (2011, January). The Janus-headed salvation: Sovereign and bank credit risk premia during 2008-2009. Economics Letters, pp. 28-31. 
Eser, F., \& Schwaab, B. (2013). Assessing asset purchases within the ECB's securities markets programme. ECB Working Paper No. 1587.

Fontana, A., \& Scheicher, M. (2010). An analysis of euro area sovereign CDS and their relation with government bonds. ECB Working Paper No. 1271.

Forbes, K., \& Rigobon, R. (2002). No Contagion, Only Interdependence: Measuring Stock Market Comovements. Journal of Finance, Vol. 18(4), pp. 2223-2261.

Fratzscher, M., Lo Duca, M., \& Straub, R. (2012, October). A global monetary tsunami? On the spillovers of US Quantitative Easing. CEPR Discussion Paper No. 9195.

Fratzscher, M., Schneider, D., \& van Robays, I. (2013). Oil prices, exchange rates, and asset prices. DIW Discussion Papers 1302.

Gagnon, J., Raskin, M., Remache, J., \& Sack, B. (2011). Large-scale asset purchases by the federal reserve: did they work? Federal Reserve Bank of New York Staff Reports, no. 441.

Gerlach, S., \& Schulz, A. (2010, May). Banking and Sovereign Risk in the Euro Area. CEPR Discussion Paper No. 7833.

Kallestrup, R., Lando, D., \& Murgoci, A. (2013, March 28). Financial Sector Linkages and the Dynamics of Bank and Sovereign Credit Spreads. mimemo.

Leonello, A. (2013). Government Guarantees and the Two-Way Feedback between Banking and Sovereign Debt Crises. mimemo.

Longstaff, F., Pan, J., Pedersen, L., \& Singleton, L. (2011). How sovereign is sovereign credit risk? American Economic Journal: Macroeconomics (3), pp. 75-103.

Manganelli, S. (2012). The Impact of the Securities Markets Programme. ECB Research Bulletin 17.

Merler, S., \& Pisani-Ferry, J. (2012, April). Hazardous tango: sovereign-bank interdependence and financial stability in the euro area. Financial Stability Review, pp. 201-210.

Mody, A., \& Sandri, D. (2012, April ). The eurozone crisis: how banks and sovereigns came to be joined at the hip. Economic Policy, pp. 199-230.

Palladini, G., \& Portes, R. (2011, November). Sovereign CDS and Bond Pricing Dynamics in the Euro-area. NBER Working Paper No. 17586.

Rigobon, R. (2003). Identification through Heteroskedasticity. The Review of Economics and Statistics, pp. 85 (4), 777-792.

Sentana, E., \& Fiorentini, G. (2001). Identification, Estimation and Testing of Conditionally Heteroskedastic Factor Model. Journal of Econometrics, pp. 102, 143-164.

Stanga, I. (2011, August). Sovereign and Bank Credit Risk during the Global Financial Crisis. DNB Working Paper, No. 314.

Stolz, S., \& Wedow, M. (2010, July 8). Extraordinary Measures in Extraordinary Times: Public Measures in Support of the Financial Sector in the EU and the United States. ECB Occasional Paper No. 117. 
Tobin, J. (1958). Liquidity preference as behavior towards risk. Review of Economic Studies 25(2), pp. 65-86.

Vayanos, D., \& Vila, J.-L. (2009). A preferred-habitat model of the term structure of interest rates. Working Paper 15487, National Bureau of Economic Research. 


\section{Figures}

Figure 1: Rolling correlation between sovereign credit risk and bank credit risk in the euro area

The figure shows the 200 days rolling correlation between the first differences of the average credit default swap spread (five year, senior) of the sovereign sector of the euro area and of the banking sector over the sample period.

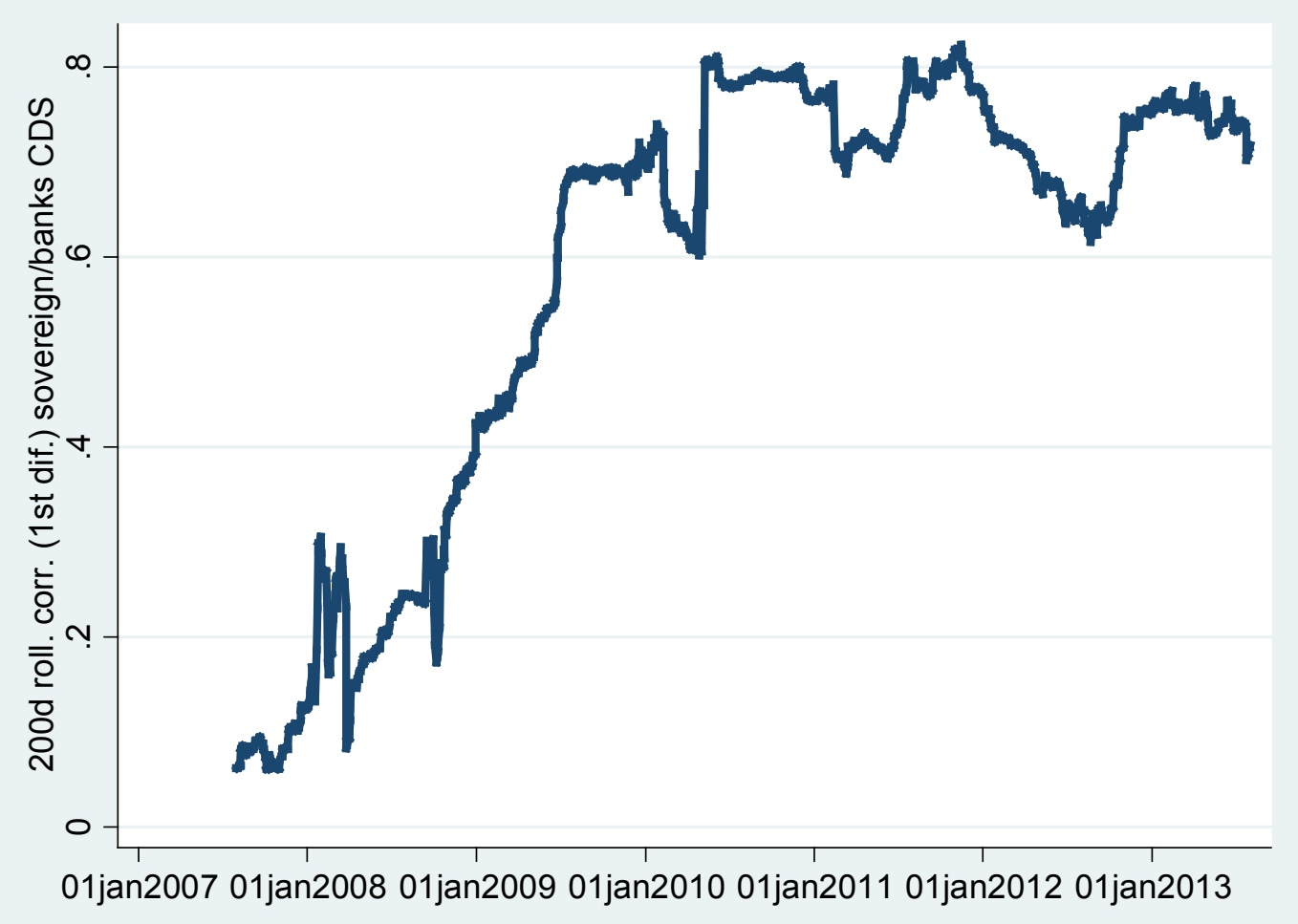


Figure 2: Time line, regime definition, and rolling standard deviations of sovereign risk and bank risk of the euro area

This figure shows (a) a time line of the global financial and the European debt crisis, (b) the definition of volatility regimes 1-7 (green solid line, right axis), and (c) the 200 days rolling standard deviations of the first difference of the average credit default swap spread (senior, five year) of the sovereign sector of the euro area and of the banking sector, respectively (blue dashed and red dotted line, left axis).

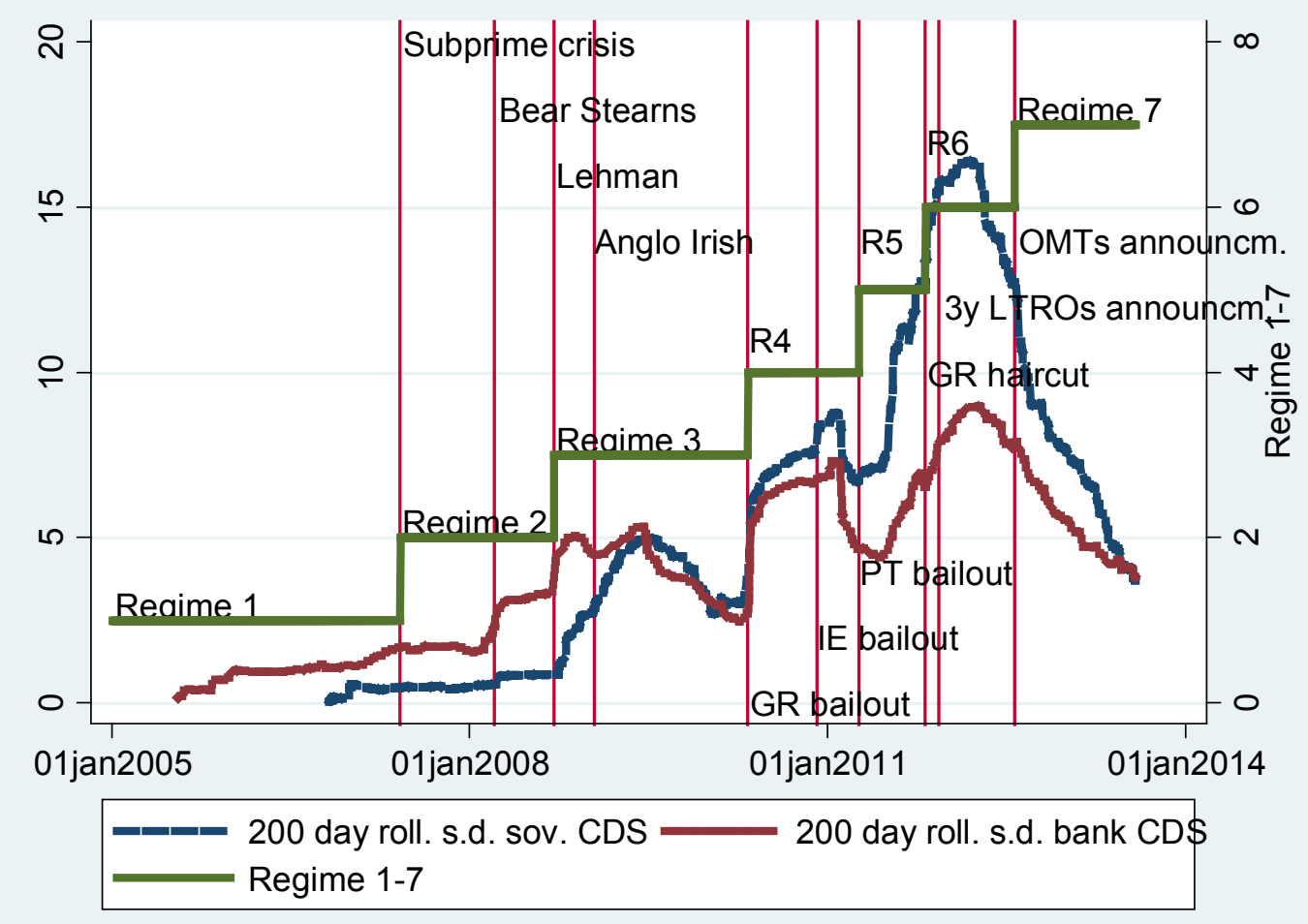


Figure 3: Actual and implied correlation between sovereign risk and bank of the euro area driven by different types of shocks

The figure shows the actual 200 days rolling correlation between sovereign risk and bank risk of the euro area and the implied correlations. The latter are explained by a specific shock type according to its estimated historical contribution to the sovereign risk variable and bank risk variable.
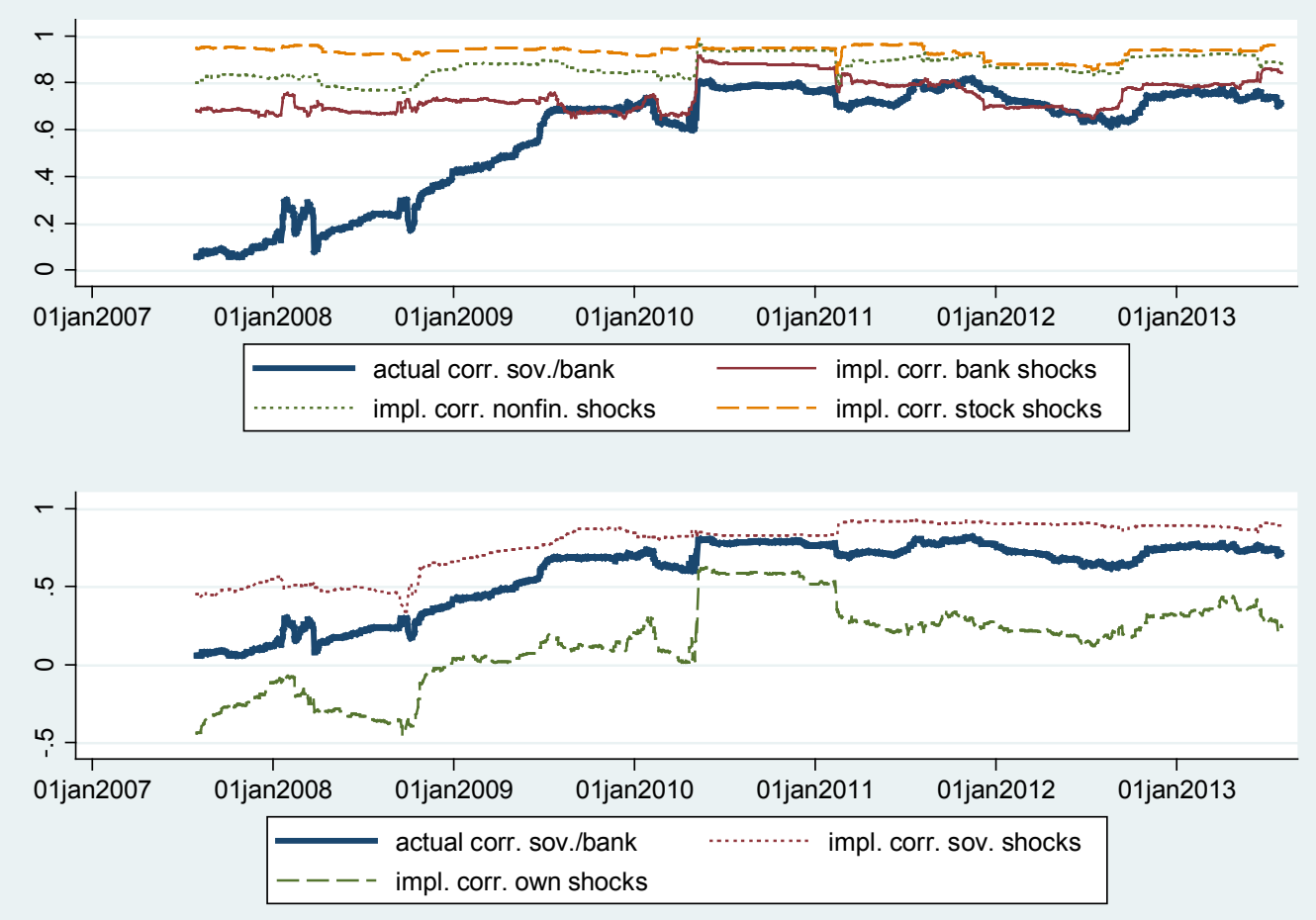
Figure 4: Overall effects between sovereign risk and bank risk of the euro area and in member states in recursive sup samples

The figure shows the overall effect from sovereign risk on bank risk (thin solid line) and vice versa (thick dashed line). They are extracted from corresponding $A^{-1}$ matrices which are estimated on recursive sup samples of the euro area en bloc and single countries. The letters .a, .b, .c denote significance at the $1 \%$, $5 \%, 10 \%$ levels.
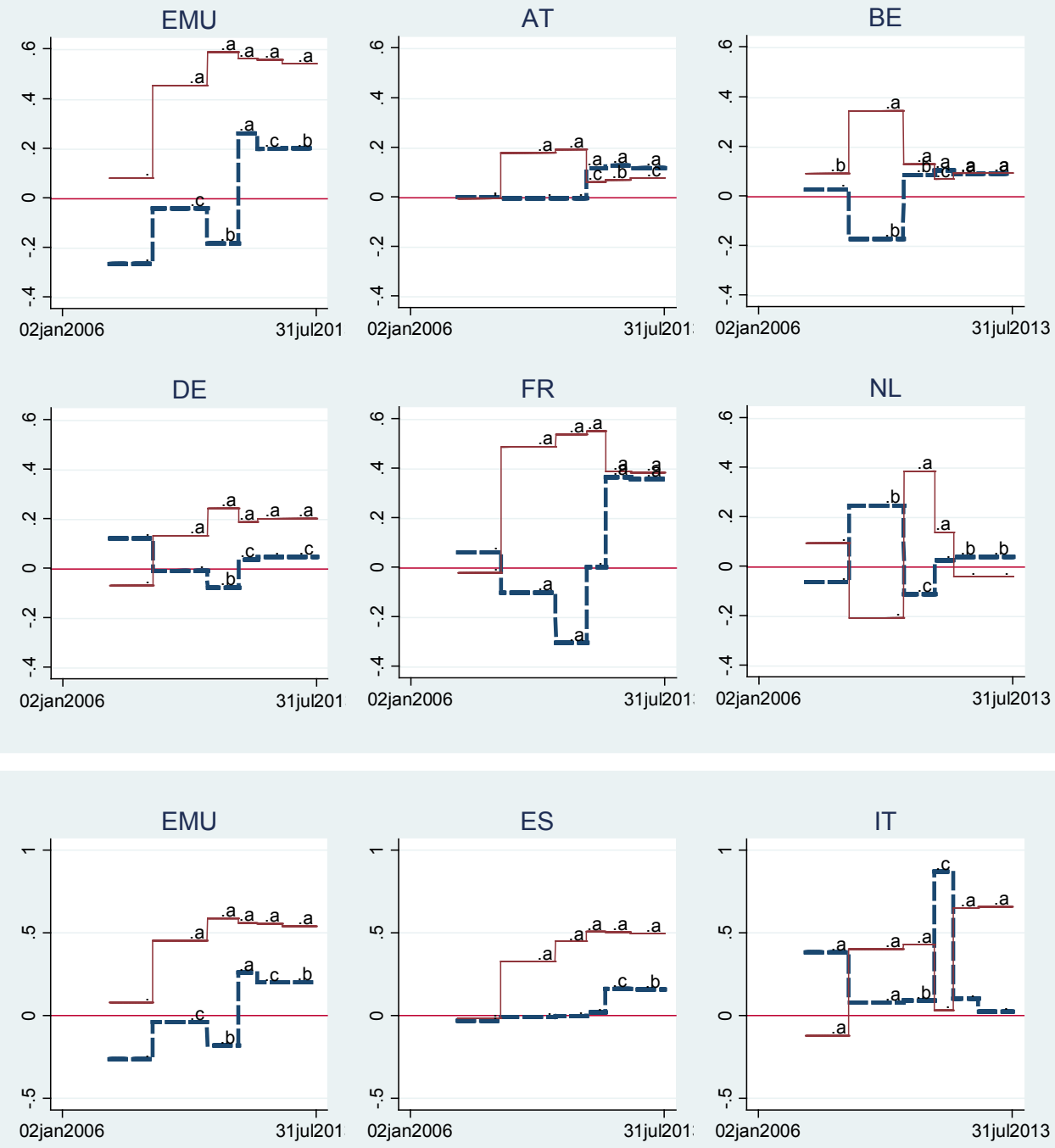

GR
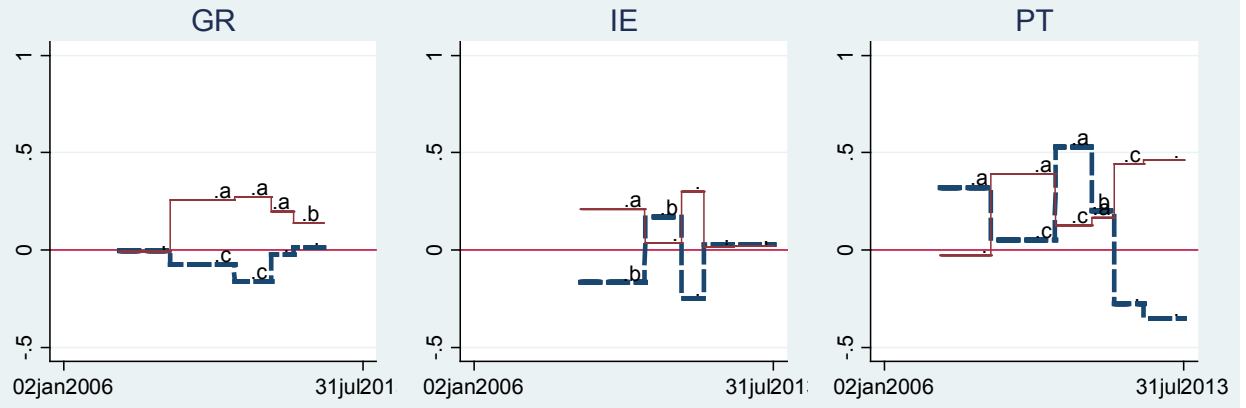


\section{Tables}

Table 1: Direct and overall effects among endogenous variables at the euro area level: $A$ and $A^{-1}$ matrix

The table shows the estimated direct and overall effects of structural shocks of one standard deviation on the endogenous variables, based on a five-variable structural VAR for the euro area. Impulse variables are in columns, response variables are in rows. The sample period is 24 October 2006 until 31 July 2013.

\begin{tabular}{|c|c|c|c|c|c|}
\hline Response & $\begin{array}{l}\text { Impulse } \\
\text { Sov. risk }\end{array}$ & Bank risk & Nonfin. risk & Term spread & Stock marke \\
\hline \multicolumn{6}{|c|}{ Direct effects } \\
\hline Sov. risk & 1.00 & 0.14 & 0.02 & 0.06 & -0.11 \\
\hline$p$ & . &.$c$ & . &.$c$ & $a$ \\
\hline Bank risk & 0.46 & 1.00 & 0.21 & -0.09 & -0.09 \\
\hline$p$ &.$a$ & . &.$a$ & . &.$a$ \\
\hline Nonfin. risk & 0.06 & 0.07 & 1.00 & 0.12 & -0.33 \\
\hline$p$ &.$a$ &.$b$ & $\cdot$ &.$a$ &.$a$ \\
\hline Term spread & 0.32 & 0.29 & -0.31 & 1.00 & 0.09 \\
\hline$p$ &.$a$ &.$b$ &.$a$ & . & . \\
\hline Stock market & -0.09 & -0.12 & -0.11 & 0.04 & 1.00 \\
\hline$p$ &.$a$ &.$a$ &.$a$ & . & . \\
\hline \multicolumn{6}{|c|}{$\underline{\text { Overall effects }}$} \\
\hline Sov. risk & 1.13 & 0.20 & 0.07 & 0.05 & -0.16 \\
\hline$p$ &.$a$ &.$b$ &.$a$ & . &.$a$ \\
\hline Bank risk & 0.54 & 1.12 & 0.29 & -0.04 & -0.26 \\
\hline$p$ &.$a$ &.$a$ &.$a$ & . &.$a$ \\
\hline Nonfin. risk & 0.22 & 0.18 & 1.05 & 0.11 & -0.37 \\
\hline$p$ &.$a$ &.$a$ &.$a$ &.$a$ &.$a$ \\
\hline Term spread & 0.44 & 0.32 & -0.23 & 0.97 & 0.08 \\
\hline$p$ &.$a$ &.$b$ &.$a$ &.$a$ & . \\
\hline Stock market & -0.18 & -0.16 & -0.17 & 0.02 & 1.09 \\
\hline$p$ &.$a$ &.$a$ &.$a$ & . &.$a$ \\
\hline
\end{tabular}

Notes: .a, .b, .c denote significance at the 1\%,5\%,10\% levels; number of observations 1764 . 
Table 2: Overall effects between sovereign risk and bank risk in individual euro area member states

The tables show the contemporaneous overall effects between sovereign risk and bank risk in euro area member states, extracted from the corresponding country-level $A^{-1}$ matrices.

\begin{tabular}{rcccccc}
\hline & Country & & & & & \\
& EMU & AT & BE & DE & ES & FR \\
\hline Bank on sov. risk & 0.20 & 0.12 & 0.09 & 0.05 & 0.16 & 0.36 \\
$p$ &.$b$ &.$a$ &.$a$ &.$b$ &.$b$ &.$a$ \\
Sov. on bank risk & 0.54 & 0.08 & 0.09 & 0.20 & 0.50 & 0.38 \\
$p$ &.$a$ &.$b$ &.$a$ &.$a$ &.$a$ &.$a$ \\
& & & & & & \\
Observations & 1764 & 2477 & 2142 & 2470 & 1765 & 2074 \\
\hline
\end{tabular}

Notes: .a, .b, .c denote significance at the $1 \%, 5 \%, 10 \%$ levels.

\begin{tabular}{rccccc}
\hline & Country & & & & \\
& GR & IE & IT & NL & PT \\
\hline Bank on sov. risk & -0.00 & 0.03 & 0.03 & 0.04 & -0.35 \\
$p$ &. &. &. &.$b$ &. \\
Sov. on bank risk & 0.12 & 0.02 & 0.66 & -0.04 & 0.46 \\
$p$ &.$b$ &. &.$a$ &. &. \\
Observations & 1571 & 1466 & 2454 & 1765 & 2003 \\
\hline
\end{tabular}

Notes: .a, .b, .c denote significance at the $1 \%, 5 \%, 10 \%$ levels. 
Table 3: Overall effects among euro area core and periphery sovereign risk and bank risk

The table shows the estimated overall effects of structural shocks of one standard deviation on the endogenous variables for the euro area core (CO) and periphery (PE) and other asset prices. They are extracted from the $A^{-1}$ matrix of a seven-variable structural VAR. Impulse variables are in columns, response variables are in rows. The sample period is 24 October 2006 until 31 July 2013.

\begin{tabular}{rccccccc}
\hline & Impulse & & & & & & \\
Response & Sov CO & Bank CO & Sov PE & Bank PE & $\begin{array}{c}\text { Nonfin } \\
\text { EA }\end{array}$ & Term EA & $\begin{array}{c}\text { Stocks } \\
\text { EA }\end{array}$ \\
\hline Sov CO & 1.15 & 0.15 & 0.54 & 0.07 & 0.09 & -0.11 & -0.21 \\
$p$ &.$a$ &.$a$ &.$a$ &.$c$ &.$a$ &.$c$ &.$a$ \\
Bank CO & 0.36 & 1.12 & 0.34 & 0.52 & 0.40 & -0.08 & -0.37 \\
$p$ &.$a$ &.$a$ &.$a$ &.$a$ &.$a$ &. &.$a$ \\
Sov PE & 0.29 & 0.08 & 1.18 & 0.11 & 0.06 & 0.02 & -0.14 \\
$p$ &.$a$ &.$a$ &.$a$ &.$c$ &.$a$ &. &.$a$ \\
Bank PE & 0.39 & 0.21 & 0.59 & 1.14 & 0.21 & -0.03 & -0.22 \\
$p$ &.$a$ &.$a$ &.$a$ &.$a$ &.$a$ &. &.$a$ \\
Nonfin EA & 0.17 & 0.04 & 0.21 & 0.15 & 1.05 & 0.09 & -0.36 \\
$p$ &.$a$ &.$c$ &.$a$ &.$a$ &.$a$ &.$b$ &.$a$ \\
Term EA & 0.30 & 0.08 & 0.46 & 0.25 & -0.22 & 0.95 & 0.16 \\
$p$ &.$a$ &.$c$ &.$a$ &.$a$ &.$a$ &.$a$ &.$b$ \\
Stocks EA & -0.18 & -0.04 & -0.14 & -0.13 & -0.17 & 0.01 & 1.09 \\
$p$ &.$a$ &.$b$ &.$a$ &.$a$ &.$a$ &. &.$a$ \\
\hline
\end{tabular}

Notes: a, .b, .c denote significance at the $1 \%, 5 \%, 10 \%$ levels. 1764 observations 


\section{Table 4: Variance decomposition for euro area core and periphery specification}

The table shows the weighted average (across regimes) of one day ahead forecast error variance decompositions, based on the seven-variable structural VAR. The weights are the number of observations per regime. The sample period is 24 October 2006 until 31 July 2013.

\begin{tabular}{lccccccc}
\hline Response & $\begin{array}{c}\text { Impulse } \\
\text { Sov CO }\end{array}$ & $\begin{array}{c}\text { Bank } \\
\text { CO }\end{array}$ & Sov PE & Bank PE & $\begin{array}{c}\text { Nonfin } \\
\text { EA }\end{array}$ & $\begin{array}{c}\text { Term } \\
\text { EA }\end{array}$ & $\begin{array}{c}\text { Stocks } \\
\text { EA }\end{array}$ \\
\hline Sov CO & 0.72 & 0.04 & 0.16 & 0.00 & 0.02 & 0.03 & 0.04 \\
Bank CO & 0.05 & 0.61 & 0.06 & 0.12 & 0.10 & 0.00 & 0.05 \\
Sov PE & 0.07 & 0.02 & 0.86 & 0.01 & 0.01 & 0.00 & 0.03 \\
Bank PE & 0.08 & 0.08 & 0.16 & 0.56 & 0.08 & 0.00 & 0.04 \\
Nonfin EA & 0.02 & 0.00 & 0.04 & 0.02 & 0.82 & 0.01 & 0.08 \\
Term EA & 0.04 & 0.00 & 0.09 & 0.02 & 0.03 & 0.80 & 0.01 \\
Stocks EA & 0.03 & 0.00 & 0.02 & 0.02 & 0.04 & 0.00 & 0.89 \\
\hline
\end{tabular}


Table 5: Flight-to-safety - Overall effects between Bund yields and other asset prices

The table shows the estimated overall effects of structural shocks of one standard deviation on the endogenous variables. It contains the $A^{-1}$ matrix of a seven-variable structural VAR, using only German CDS spreads to measure core sovereign risk and the 10 year yield on German sovereign bonds. Impulse variables are in columns, response variables are in rows. The sample period is 24 October 2006 until 31 July 2013.

\begin{tabular}{rccccccc}
\hline & Impulse & & & & & & \\
Response & Sov DE & Bank & Sov PE & Bank PE & Nonfin & $\begin{array}{c}\text { Bund } \\
\text { EA }\end{array}$ & $\begin{array}{c}\text { Stocks } \\
\text { EA }\end{array}$ \\
\hline Sov DE & 1.04 & 0.06 & 0.11 & 0.16 & 0.05 & 0.05 & -0.17 \\
$p$ &.$a$ &.$b$ &. &.$c$ &.$c$ &. &.$a$ \\
Bank CO & 0.23 & 1.09 & 0.29 & 0.58 & 0.39 & -0.05 & -0.31 \\
$p$ &.$a$ &.$a$ &.$a$ &.$a$ &.$a$ &. &.$a$ \\
Sov PE & 0.26 & 0.05 & 1.07 & 0.09 & 0.06 & -0.05 & -0.10 \\
$p$ &.$b$ &.$c$ &.$a$ &.$c$ &.$a$ &.$b$ &.$a$ \\
Bank PE & 0.21 & 0.17 & 0.54 & 1.15 & 0.20 & -0.05 & -0.19 \\
$p$ &.$a$ &.$a$ &.$a$ &.$a$ &.$a$ &.$b$ &.$a$ \\
Nonfin EA & 0.07 & 0.05 & 0.19 & 0.17 & 1.07 & 0.05 & -0.36 \\
$p$ &.$b$ &.$c$ &.$a$ &.$a$ &.$a$ &. &.$a$ \\
Bund yield & -0.14 & 0.03 & -0.21 & -0.07 & -0.26 & 1.00 & 0.43 \\
$p$ &.$a$ &. &.$a$ &.$b$ &.$a$ &.$a$ &.$a$ \\
Stocks EA & -0.09 & -0.04 & -0.13 & -0.15 & -0.17 & 0.03 & 1.09 \\
$p$ &.$a$ &.$c$ &.$a$ &.$a$ &.$a$ &. &.$a$ \\
\hline
\end{tabular}

Notes: .a, .b, .c denote significance at the 1\%, 5\%, 10\% levels. 1764 observations. 
Table 6: Implementation and announcement effects of monetary policy on credit risks and other asset prices in the euro area

The table shows the effects of on non-standard monetary policy measures on the endogenous variables, based on the five-variable, structural VAR specification for the euro area. The dependent variables are in basis points in columns (1)-(4) and in percentage in column (5). The upper part of the table shows the point estimates and the cumulative implementation effects of monetary policy measures. The lower part shows the cumulative effects of specific ECB announcements together with the p-value of the F-test of joint significance of lags 0-10.

\begin{tabular}{|c|c|c|c|c|c|}
\hline & $\begin{array}{c}(1) \\
\text { Sov. risk }\end{array}$ & $\begin{array}{c}(2) \\
\text { Bank risk }\end{array}$ & $\begin{array}{c}\text { (3) } \\
\text { Non-fin. risk }\end{array}$ & $\begin{array}{c}\text { (4) } \\
\text { Term spread }\end{array}$ & $\begin{array}{c}(5) \\
\text { Stock market }\end{array}$ \\
\hline \multicolumn{6}{|l|}{ Implementation effects } \\
\hline \multicolumn{6}{|c|}{ 6-12m LTRO allotm. (bn.) } \\
\hline Point estimate & -0.011 & -0.008 & -0.011 & 0.002 & 0.003 \\
\hline$p$ & 0.003 & 0.006 & 0.000 & 0.695 & 0.000 \\
\hline Cum. effect (979 bn.) & -10.7 & -7.8 & -10.7 & - & 2.9 \\
\hline \multicolumn{6}{|l|}{ 3y LTRO allotments (bn.) } \\
\hline Point estimate & -0.030 & -0.047 & 0.006 & 0.004 & -0.000 \\
\hline$p$ & 0.431 & 0.001 & 0.257 & 0.803 & 0.846 \\
\hline Cum. Effect (1,020 bn) & - & -47.9 & - & - & - \\
\hline \multicolumn{6}{|l|}{ SMP purchases (bn.) } \\
\hline Point estimate & 1.082 & 0.961 & 0.417 & 0.469 & -0.111 \\
\hline$p$ & 0.296 & 0.073 & 0.161 & 0.235 & 0.211 \\
\hline Cum. Effect (218 bn) & - & 209.3 & - & - & - \\
\hline \multicolumn{6}{|l|}{ Cum. announcm. effects } \\
\hline LTROs 6-12 months & -5.9 & -1.0 & 3.8 & 8.8 & -0.6 \\
\hline$p$ & 0.031 & 0.138 & 0.439 & 0.001 & 0.511 \\
\hline 3-year LTROs & 39.7 & 26.0 & 9.6 & -13.8 & -8.1 \\
\hline$p$ & 0.000 & 0.000 & 0.000 & 0.000 & 0.000 \\
\hline SMP & -52.0 & -40.0 & -16.2 & -54.2 & 3.1 \\
\hline$p$ & 0.000 & 0.000 & 0.000 & 0.000 & 0.000 \\
\hline OMT & -56.0 & -33.7 & -7.9 & -15.2 & 5.1 \\
\hline$p$ & 0.000 & 0.000 & 0.000 & 0.000 & 0.001 \\
\hline $\mathrm{R}$ squared & 0.24 & 0.33 & 0.37 & 0.24 & 0.60 \\
\hline
\end{tabular}

Note: The p-values are based on heteroskedasticity robust standard errors; 1764 observations. 


\section{Table 7: Implementation and announcement effects of monetary policy on sovereign credit risk of euro area member states}

The table shows the effects of non-standard monetary policy measures by the ECB on sovereign CDS spreads of euro area countries, based on the sovereign risk equation of the corresponding country-specific sVAR specification. The dependent variable is in basis points. The upper part of the table shows the implementation effects of specific monetary policy measures. The lower part shows the cumulative announcement effects of specific ECB measures together with the p-value of the F-test of joint significance of lags $0-10$.

\begin{tabular}{|c|c|c|c|c|c|c|c|c|c|c|c|}
\hline & EMU & $\mathrm{AT}$ & $\mathrm{BE}$ & $\mathrm{DE}$ & FR & $\mathrm{NL}$ & ES & $\mathrm{IE}$ & GR & IT & $\mathrm{PT}$ \\
\hline \multicolumn{12}{|l|}{ Implementation effects } \\
\hline 6-12m LTRO allotm. (bn.) & -0.011 & -0.017 & -0.007 & -0.003 & -0.002 & -0.010 & -0.012 & -0.020 & -0.057 & -0.022 & -0.013 \\
\hline$p$ & 0.003 & 0.000 & 0.064 & 0.074 & 0.171 & 0.005 & 0.012 & 0.002 & 0.429 & 0.000 & 0.214 \\
\hline Cum. effect 6-12m LTROs & -10.7 & -16.6 & -6.9 & -2.9 & - & -9.8 & -11.7 & -19.6 & - & -21.5 & - \\
\hline 3y LTRO allot. (bn.) & -0.030 & -0.016 & -0.048 & -0.009 & -0.030 & -0.011 & -0.067 & -0.015 & -5.272 & -0.092 & -0.000 \\
\hline$p$ & 0.431 & 0.112 & 0.192 & 0.254 & 0.137 & 0.253 & 0.001 & 0.809 & 0.149 & 0.086 & 0.999 \\
\hline Cum. effect 3y LTROs & - & - & - & - & - & - & -68.3 & - & - & -93.8 & - \\
\hline \multirow[t]{2}{*}{ SMP purchases (bn.) } & 1.082 & 0.568 & 1.188 & 0.112 & 0.327 & 0.784 & 1.096 & -0.504 & 61.756 & 2.137 & 3.542 \\
\hline & 0.296 & 0.595 & 0.190 & 0.852 & 0.567 & 0.107 & 0.391 & 0.740 & 0.019 & 0.186 & 0.323 \\
\hline \multicolumn{12}{|l|}{ Cum. announcm. effects } \\
\hline LTRO 6-12 months & -5.9 & -3.6 & 1.2 & -1.3 & 3.0 & -4.6 & -7.4 & -3.6 & -199.6 & -6.4 & -39.2 \\
\hline$p$ & 0.031 & 0.075 & 0.006 & 0.087 & 0.020 & 0.000 & 0.387 & 0.019 & 0.857 & 0.070 & 0.204 \\
\hline 3-year LTROs & 39.7 & 25.0 & 47.4 & 15.1 & 52.3 & 54.4 & 48.1 & 67.0 & 4971.8 & 42.8 & 75.4 \\
\hline$p$ & 0.000 & 0.000 & 0.000 & 0.000 & 0.000 & 0.000 & 0.000 & 0.000 & 0.000 & 0.000 & 0.000 \\
\hline SMP & -52.0 & -20.3 & -40.6 & -10.2 & -11.5 & -30.1 & -79.8 & 30.9 & -2139.9 & -113.0 & -132.1 \\
\hline$p$ & 0.000 & 0.013 & 0.000 & 0.058 & 0.000 & 0.000 & 0.000 & 0.000 & 0.000 & 0.000 & 0.000 \\
\hline OMT & -56.0 & -10.9 & -23.4 & -8.2 & -25.0 & -21.9 & -114.0 & -80.0 & 0.0 & -106.9 & -124.2 \\
\hline$p$ & 0.000 & 0.000 & 0.000 & 0.000 & 0.000 & 0.000 & 0.000 & 0.000 & - & 0.000 & 0.000 \\
\hline Observations & 1764 & 2477 & 2142 & 2470 & 2074 & 1765 & 1765 & 1466 & 1583 & 2454 & 2003 \\
\hline $\mathrm{R}$ squared & 0.24 & 0.15 & 0.20 & 0.15 & 0.18 & 0.27 & 0.26 & 0.22 & 0.25 & 0.27 & 0.18 \\
\hline
\end{tabular}

Note: The p-values are based on heteroskedasticity robust standard errors. 


\section{Table 8: Implementation and announcement effects of monetary policy on bank credit risk of euro area member states}

The table shows the effects of non-standard monetary policy measures by the ECB on bank CDS spreads (in basis points) of euro area countries, based on the bank risk equation of the corresponding country-specific sVAR specification. The dependent variable is in basis points. The upper part of the table shows the implementation effects of specific monetary policy measures. The lower part shows the cumulative announcement effects.

\begin{tabular}{|c|c|c|c|c|c|c|c|c|c|c|c|}
\hline & EMU & $\mathrm{AT}$ & $\mathrm{BE}$ & $\mathrm{DE}$ & FR & NL & ES & $\mathrm{IE}$ & GR & IT & $\mathrm{PT}$ \\
\hline \multicolumn{12}{|l|}{ Implementation effects } \\
\hline 6-12m LTRO allotm. (bn.) & -0.008 & -0.014 & -0.002 & -0.005 & -0.013 & -0.007 & -0.007 & -0.022 & 0.026 & -0.010 & -0.005 \\
\hline$p$ & 0.006 & 0.004 & 0.855 & 0.184 & 0.001 & 0.030 & 0.152 & 0.211 & 0.569 & 0.079 & 0.254 \\
\hline Cum. effect 6-12m LTROs & -7.8 & -13.7 & - & - & -12.7 & -6.9 & - & - & - & -7.8 & - \\
\hline 3y LTRO allotments (bn.) & -0.047 & -0.039 & -0.080 & -0.042 & -0.031 & -0.004 & -0.066 & -0.016 & -0.356 & -0.052 & -0.134 \\
\hline$p$ & 0.001 & 0.022 & 0.023 & 0.000 & 0.051 & 0.316 & 0.026 & 0.677 & 0.543 & 0.002 & 0.036 \\
\hline Cum. effect 3y LTROs & -47.9 & -39.8 & -81.6 & -42.8 & -30.6 & & -67.3 & & & -53.0 & -137.7 \\
\hline SMP purchases (bn.) & 0.961 & 1.666 & 1.509 & 0.749 & 1.016 & 0.331 & 0.622 & -2.341 & 8.800 & 1.592 & 1.634 \\
\hline$p$ & 0.073 & 0.033 & 0.134 & 0.077 & 0.196 & 0.448 & 0.391 & 0.481 & 0.024 & 0.084 & 0.314 \\
\hline Cum. effect SMP & 209.3 & 361.9 & - & 163.3 & - & - & - & - & $1,918.4$ & 346.6 & - \\
\hline \multicolumn{12}{|l|}{ Cum. announcm. effects } \\
\hline LTRO 6-12 months & -1.0 & -1.9 & 18.7 & 6.7 & 4.2 & -5.4 & 21.2 & 37.9 & 2.0 & -14.6 & -4.5 \\
\hline$p$ & 0.138 & 0.087 & 0.085 & 0.021 & 0.555 & 0.614 & 0.001 & 0.613 & 0.280 & 0.142 & 0.154 \\
\hline 3-year LTROs & 26.0 & 2.9 & 68.1 & 25.1 & 25.3 & -0.3 & 38.9 & -74.3 & 216.7 & 8.6 & 80.7 \\
\hline$p$ & 0.000 & 0.000 & 0.000 & 0.000 & 0.000 & 0.000 & 0.000 & 0.000 & 0.000 & 0.000 & 0.000 \\
\hline SMP & -40.0 & -43.4 & -23.6 & -33.1 & -39.5 & -0.5 & -52.1 & 196.4 & -473.5 & -63.0 & -79.1 \\
\hline$p$ & 0.000 & 0.000 & 0.546 & 0.086 & 0.551 & 0.016 & 0.001 & 0.000 & 0.082 & 0.000 & 0.000 \\
\hline OMT & -33.7 & -39.7 & -23.6 & -5.6 & -20.6 & -14.0 & -54.5 & 21.5 & 0.0 & -71.2 & -61.0 \\
\hline$p$ & 0.000 & 0.000 & 0.000 & 0.000 & 0.000 & 0.000 & 0.000 & 0.139 & - & 0.000 & 0.477 \\
\hline Observations & 1764 & 2477 & 2142 & 2470 & 2074 & 1765 & 1765 & 1466 & 1584 & 2454 & 2003 \\
\hline R squared & 0.33 & 0.18 & 0.19 & 0.16 & 0.26 & 0.11 & 0.28 & 0.11 & 0.27 & 0.29 & 0.20 \\
\hline
\end{tabular}

Note: The p-values are based on heteroskedasticity robust standard errors. 


\section{Table 9: Effects of bank bailout announcements on sovereign risk and bank risk in the euro area}

The lower part of the table shows the effects of specific bank bailout announcements (debt guarantees, deposit guarantees, capital injections) by governments on sovereign CDS spreads (columns 1-3) and bank $C D S$ spreads (columns 4-6). They are extracted from the sovereign risk equation and bank risk equation, respectively, of the five-variable sVAR for the euro area. Specifically, the table shows the 20 day cumulative announcement effects together with the p-value of the F-test of joint significance of lags 0-20. The dependent variables are in basis points. The upper part of the table shows the implementation effects of specific monetary policy measures. The lower part shows in addition the cumulative effect of the announcement of specific ECB measures together with the p-value of the F-test of joint significance.

\begin{tabular}{|c|c|c|c|c|c|c|}
\hline & \multicolumn{3}{|c|}{ Sovereign risk } & \multicolumn{3}{|c|}{ Bank risk } \\
\hline & $(1)$ & $(2)$ & (3) & (4) & $(5)$ & (6) \\
\hline \multicolumn{7}{|c|}{$\begin{array}{l}\text { Implementation effects, point } \\
\text { estimates }\end{array}$} \\
\hline 6-12m LTROs allotm. (bn.) & -0.01 & -0.01 & -0.01 & -0.01 & -0.01 & -0.01 \\
\hline$p$ & 0.009 & 0.000 & 0.001 & 0.044 & 0.008 & 0.003 \\
\hline 3y LTROs allotments (bn.) & -0.03 & -0.03 & -0.03 & -0.05 & -0.05 & -0.05 \\
\hline$p$ & 0.425 & 0.412 & 0.425 & 0.000 & 0.000 & 0.000 \\
\hline SMP purchases (bn.) & 1.10 & 1.11 & 1.10 & 0.97 & 0.95 & 0.96 \\
\hline$p$ & 0.283 & 0.272 & 0.280 & 0.063 & 0.064 & 0.066 \\
\hline \multicolumn{7}{|l|}{ Cum. announcement effects } \\
\hline \multicolumn{7}{|c|}{ Monetary policy announcements } \\
\hline LTROs 6-12 months & -6.5 & -13.7 & -5.4 & 1.6 & -0.1 & 2.2 \\
\hline$p$ & 0.110 & 0.024 & 0.058 & 0.431 & 0.184 & 0.091 \\
\hline 3-year LTROs & 40.8 & 41.0 & 40.8 & 27.6 & 28.0 & 27.4 \\
\hline$p$ & 0.000 & 0.000 & 0.000 & 0.000 & 0.000 & 0.000 \\
\hline SMP & -52.6 & -50.0 & -54.5 & -42.0 & -43.1 & -43.2 \\
\hline$p$ & 0.000 & 0.000 & 0.000 & 0.000 & 0.000 & 0.000 \\
\hline OMT & -54.4 & -55.6 & -54.6 & -32.2 & -32.1 & -32.5 \\
\hline$p$ & 0.000 & 0.000 & 0.000 & 0.000 & 0.000 & 0.000 \\
\hline \multicolumn{7}{|l|}{ Bank bailout announcements } \\
\hline Debt guarantees & 0.9 & & & -46.6 & & \\
\hline$p$ & 0.006 & & & 0.000 & & \\
\hline Deposit guarantees & & -31.0 & & & -73.5 & \\
\hline$p$ & & 0.000 & & & 0.000 & \\
\hline Capital injections & & & 4.1 & & & -76.0 \\
\hline$p$ & & & 0.003 & & & 0.000 \\
\hline R squared & 0.26 & 0.26 & 0.26 & 0.37 & 0.39 & 0.37 \\
\hline
\end{tabular}

Note: The p-values are based on heteroskedasticity robust standard errors; 1764 observations. 


\section{Appendix - not for publication}


Appendix 1: Regime definition, stylized facts, and estimation procedure

As to the volatility regimes, regime 1 spans until 1 July 2007 when the subprime crisis emerges in the US. During regime 2, tensions are transmitted to Europe. The subprime crisis culminates in the bankruptcy of Lehman Brothers on 15 September 2008, with subsequent major stress in western financial and in particular interbank markets. Thereafter, in regime 3, a denotable European dimension of the banking crisis emerges with large scale state support for the European banking sector. Bailouts occur in nearly all euro area member states. They include liability guarantees, capital injections, and deposit insurances and amount to several trillion euro. Regime 4 begins with the bailout of the Greek sovereign by other European sovereigns on 2 May 2011, followed by the ECB's SMP, and the bailouts of the Irish and Portuguese governments, respectively. The latter marks the start of regime 5 on 6 April 2011. Expectations of a restructuring of Greek sovereign debt emerged. The Greek haircut on 27 October 2011 is the beginning of regime 6 which contains the ECB's LTROs. Regime 7 starts with the announcement of OMTs by the ECB on 26 July 2012.

The choice of events (and implied regimes) is guided by several considerations. First and foremost, the events trigger major changes in European financial market volatility which is a prerequisite for identification of the structural parameters of the model. Second, they are particularly relevant for developments in the credit market and thereby help identifying the bidirectional effects between sovereign risk and bank risk. Third, they affect all euro area countries. Therefore, we can keep the regime definition constant across specifications. This allows for a clean comparison of the results across countries. Forth, as a side product, they define sub-periods of sufficient and similar length which we can use to perform recursive estimations. There is no need for an additional definition of sub-periods which would complicate the interpretation of results.

Regarding changes in volatility, specifically in credit markets, the 200 days rolling standard deviations of euro area sovereign and bank CDS spreads start at relatively low levels in regime 1, prior to the turmoil in the US subprime market. They peak in regime 6 , after the Greek haircut. For a formal and comprehensive comparison, Table A1 shows the standard deviations of all endogenous variables for the euro area by regime. For sovereigns, the standard deviation increases by a factor of 9.0 and 31.7 when moving from regime 1 to 3 to 5, respectively. For banks, the respective factors are 2.3 and 4.3. For the other endogenous variables, the ratios of highest to lowest volatility range from 2.6 for the term spread to 10.2 for non-financial CDS spreads.

Figure A1 presents further stylised facts. The upper left panel shows 200 days rolling correlations between sovereign CDS spreads and bank CDS spreads at the country level. The upper right panel shows the average over these. The lower panels depict cross-border correlations. In particular, we divide the countries into what is usually referred to as the 
euro area core and periphery. For comparison, all panels also contain the correlation between euro area sovereign and bank risk depicted in Figure 1 (thick line).

There are several interesting features. First, the correlations fluctuate significantly over the sample period. In particular, as with the rolling standard deviations, they increase substantially during the European debt crisis. This co-movement between volatility and correlations illustrates the idea underlying our identification approach. Consider the case of bank risk. Higher volatility of bank CDS spreads is associated with higher correlations between sovereign spreads and bank spreads. We use this additional information to estimate the reaction of sovereign risk in response to bank risk shocks. Second, for the risk measures of country aggregates, the increase in correlations is of similar magnitude. Specifically, the correlation is strongly positive between core and periphery countries both within sectors-across borders and across sectors and borders. Third, while all country-specific correlations tend to increase during the European debt crisis, there is considerable heterogeneity regarding the magnitude and persistence of this pattern.

An alternative to the narrative regime definition is a purely statistical approach as, for example, in Fratzscher et al. (2013). The authors use estimated reduced form residuals, compute their rolling standard deviations, and calibrate thresholds for standard deviations to classify corresponding observations into volatility regimes. While well suited for a given specification, this approach has one main drawback for our purposes. Calibrations need to be country and sample specific to yield meaningful results. This would complicate the comparison of results. In addition, the exposition would be tedious with nearly 70 different calibrations. 


\section{Figure A1: Rolling correlations between sovereign risk and bank risk of the euro area and of}

\section{individual member states and between the euro area core and periphery}

The figure shows the 200 days rolling correlations between the CDS spread of the sovereign sector of the euro area and of the banking sector over the sample period 2004-2013. The upper left panel shows the correlation in individual member states. The upper right panel shows the average correlation across countries (thin line). The lower left panel shows the correlation between core and periphery sovereigns (thin solid line) and between core and periphery banks (dashed line). The lower right panel shows the correlation between core sovereigns and periphery banks (thin solid line) and between core banks and periphery sovereigns (dashed line). All panels also contain the correlation between sovereign risk and bank risk at the euro area level (thick line).
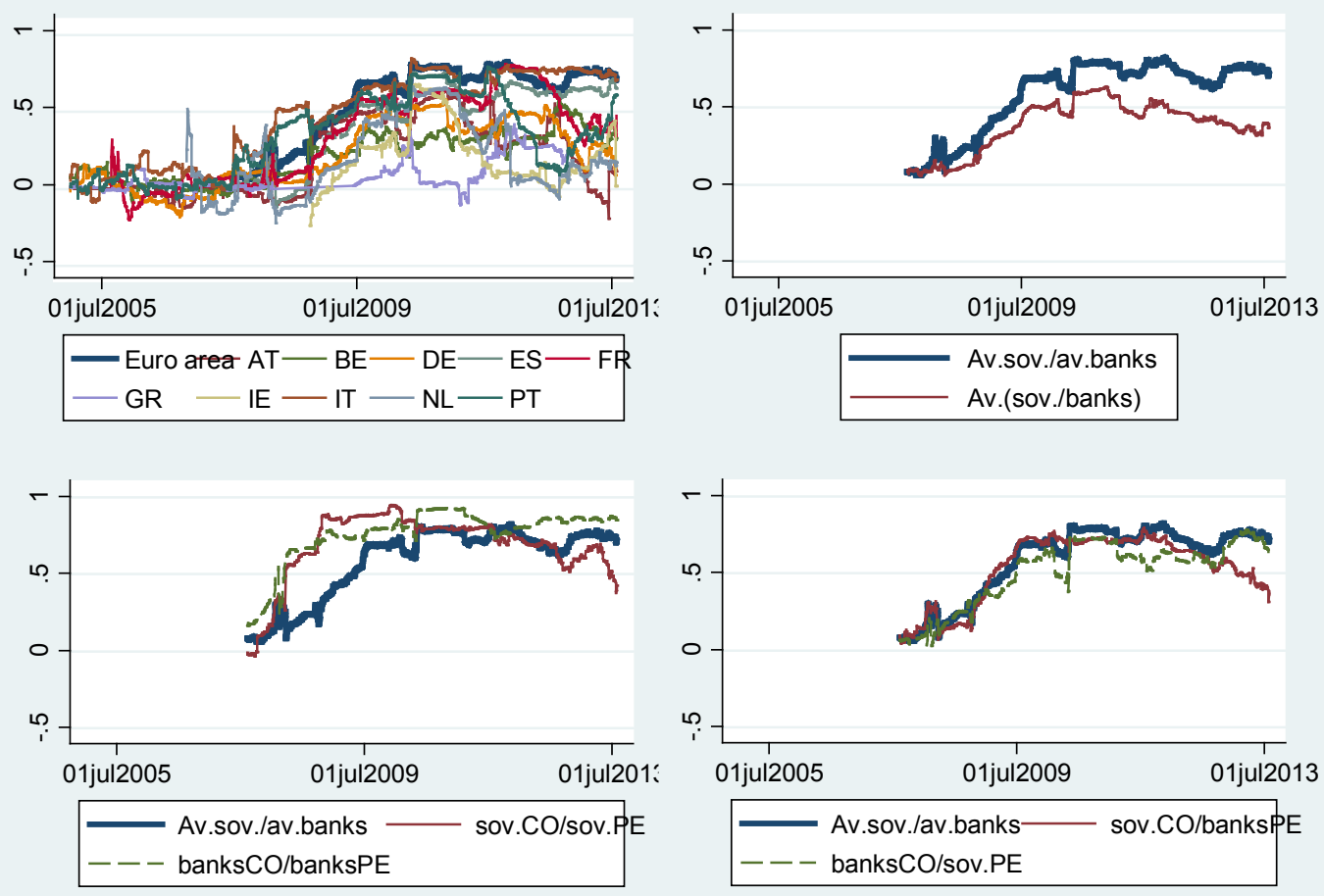


\section{Table A1: Standard deviations by volatility regime}

The table shows the standard deviations of the endogenous variables of the euro area specification by regime. Specifically, it contains the standard deviations of the first differences of the CDS spreads of sovereigns, banks, and non-financial corporations, of the term spread, and the first log difference of the Euro Stoxx 50 return index. The sample period is 24 October 2006 until 31 July 2013.

\begin{tabular}{lccccccc}
\hline Regime & $(1)$ & $(2)$ & $(3)$ & $(4)$ & $(5)$ & $(6)$ & $(7)$ \\
\hline S.d. sovereign CDS & 0.48 & 0.74 & 4.32 & 8.21 & 15.22 & 12.16 & 5.12 \\
S.d. bank CDS & 1.75 & 2.99 & 4.05 & 6.76 & 7.51 & 7.79 & 4.38 \\
S.d. non-fin. CDS & 0.49 & 5.08 & 5.08 & 3.82 & 4.27 & 4.10 & 2.87 \\
& & & & & & & \\
S.d. term spread & 2.29 & 4.11 & 4.68 & 4.55 & 5.63 & 5.92 & 3.59 \\
& & & & & & & \\
S.d. Euro Stoxx 50 & 0.79 & 1.39 & 2.18 & 1.45 & 1.98 & 1.55 & 1.14 \\
\hline Observations & 158 & 336 & 424 & 243 & 146 & 195 & 264 \\
\hline
\end{tabular}

Source: Datastream, authors own calculations. 


\section{Appendix 2: Interpretation of structural shocks}

As to the interpretation of the structural shocks, we identify them in a statistical way which gives full voice to the data regarding the sign and magnitude of impact effects. The drawback of our agnostic approach is that the estimated shocks are harder to interpret since they are not based on a priori assumptions. To see whether the identified shocks correspond to our interpretation, we check if they show higher volatility during those times that we would have expected, given our interpretation of shocks. In addition, we interpret selected single shocks for illustration. In particular, we discuss the largest shock (in absolute value) to each sovereign and bank risk variable. Both approaches help disentangling the shocks and corroborate our shock interpretation.

Figure A2 shows the structural shock series (grey bars) together with their 200 days rolling standard deviations (black line). Generally, the volatilities tend to peak around two points in time. Intuitively and reassuring, the peaks correspond to the global financial crisis in 2008/2009 and to the European debt crisis in 2011/2012. However, there are important differences regarding (a) which peak constitutes the global maximum, (b) the height of each peak, and (c) the precise timing of volatility changes.

Regarding shocks to core sovereign risk, the second volatility peak is evidently higher; approximately by a factor of two. This is plausible given that at that time the European debt crisis went into full-blown mode (see, for example, Mody and Sandri, 2012). It even called into question the sustainability of public finances of several core countries. They by then had gained massive risk exposure to the European banking and sovereign sector. In contrast, the first peak is much lower. It mirrors the steep recession which impaired public finances in these countries. In terms of single shocks, the largest (negative) shock occurred on November 30, 2011, the first trading day after euro area finance ministers agreed upon levering the EFSF.

Conversely, for shocks to core bank risk, the first volatility peak is clearly higher. Again, this squares with our shock interpretation as during this period the stress in US financial markets was transmitted to the European banking sector. In addition, banks received major rescue packages following the fall of Lehman brothers. Accordingly, the second peak is substantially lower as many credit risks on banks' balance sheets have already been transferred to the sovereign sector. Further, one can detect a third peak at the very beginning of the sample. It reflects tensions in the market for mortgage backs securities in the US which affected the European banking sector - but not the sovereign sector. Hence, it is not present in the sovereign shock series. Regarding single days, the largest bank shock materialised on September 26, 2008, when Washington Mutual failed. Finally, comparing core sectors, the locations of global maxima also supports our interpretation that bailout shocks are more important for bank risk than for sovereign risk dynamics. 
Regarding the periphery, volatilities peak during the second crisis in both sectors. This reflects that, in contrast to the core, in the periphery bank risks mostly emerged relatively late, as in Spain. Nevertheless, the increase in volatility is much more pronounced in case of sovereign shocks. It exceeds the volatility peak of bank shocks by approximately 0.5 standard deviations. This aligns with the notion that, except for Ireland, the main source of credit risk in the periphery was the sovereign sector, as with Italy and Portugal. In fact, the largest shock hits sovereign credit risk on November $1^{\text {st }}$, 2011, when Greece announced a referendum on the bailout package offered by its European partners. On the other hand, the largest (negative) bank risk shock occurred on January $3^{\text {rd }}, 2011$. On that day, the ECB announced that the Belgian Peter Praet was to succeed Jürgen Stark as a member of the executive board, instead of the German candidate Jörg Asmussen. Finally, comparing core to periphery banks, the shock series affirm our reading that the stronger link between sectors in the core resulted from larger bank bailouts.

Concerning shocks to non-financial risk and to the stock market, volatility is higher during the first crisis. This seems reasonable given that the associated recession was deeper. For term spread shocks, both peaks are of similar height. While the first spike coincides with massive downward revisions of growth expectations and aggressive monetary easing, affecting the business cycle component of the term spread, the second hike reflects elevated credit risk premia in the European government bond market. The similar importance of both components explains the largely insignificant impact effects of the term spread as the components off-set each other. 


\section{Figure A2: Interpretation of structural shocks for core-periphery specification}

The figure shows the daily structural shocks (grey bars, left axis) together with their 200 days rolling standard deviations (black line, right axis). The estimated shocks are based on a seven-variable VAR for the euro area core and periphery. The sample period is 24 October 2006 until 31 July 2013.
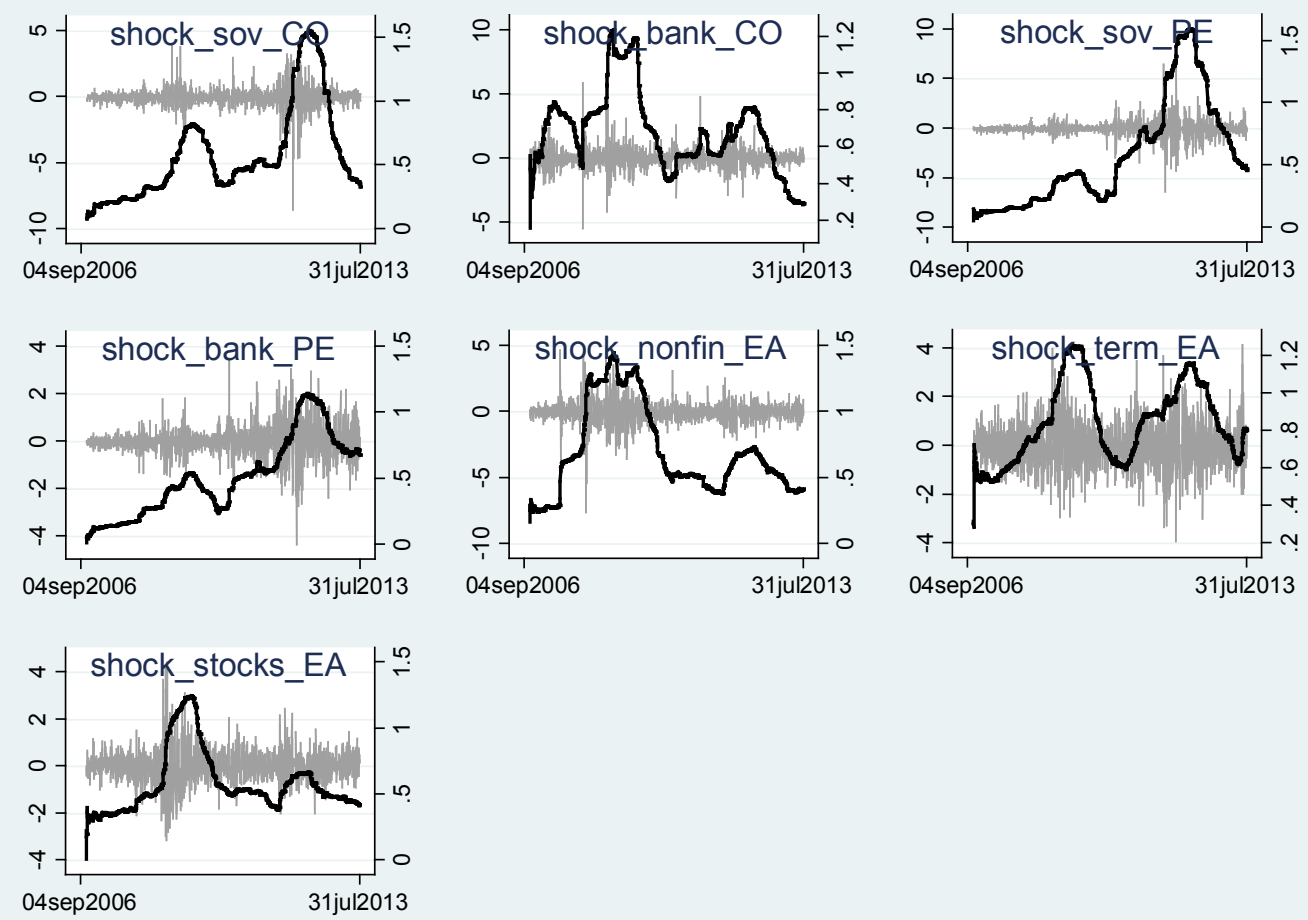


\section{Appendix 3: Variable definitions, sample periods, and sources}

\begin{tabular}{|c|c|c|c|c|c|}
\hline \multicolumn{6}{|c|}{ Endogenous variables by country } \\
\hline Sovereign CDS & Banks CDS & Non-financials CDS & Short rate* & $\begin{array}{l}\text { Stock market } \\
\text { index** }\end{array}$ & $\begin{array}{l}\text { Sample } \\
\text { start*** }\end{array}$ \\
\hline $\begin{array}{l}\text { euro area: unweighted } \\
\text { average of all } \\
\text { countries except of } \\
\text { Greece }\end{array}$ & $\begin{array}{l}\text { Unweighted average of all bank CDS } \\
\text { spreads (see below) }\end{array}$ & $\begin{array}{l}\text { Unweighted average of all non-financial corporate CDS } \\
\text { spreads (see below) }\end{array}$ & $\begin{array}{l}\text { Term spread: } \\
\text { unweighted } \\
\text { average of country } \\
\text { term spreads }\end{array}$ & Euro Stoxx 50 & 24.10 .2006 \\
\hline Austria & $\begin{array}{l}\text { Erste Group Bank, Raiffeisen Zentralbank, } \\
\text { Telekom Austria }\end{array}$ & Telekom Austria & Interbank & ATX & 20.01.2004 \\
\hline Belgium & KBC Bank & Solvay & Treasury bill & BEL 20 & 12.05 .2005 \\
\hline France & $\begin{array}{l}\text { BNP Paribas, Credit Agricole, Natixis, } \\
\text { Societe Generale }\end{array}$ & $\begin{array}{l}\text { Accor, Air France, Alstom, Capgemini, Carrefour, } \\
\text { Casino, Guipchin, Electricite de France, GDF Suez, } \\
\text { Lafarge, Legrand France, Michelin, Pernod Ricard, } \\
\text { Renault, Sanofi-Aventis, Schneider Electrical, Technip, } \\
\text { Vinci, Vivendi }\end{array}$ & Treasury bill & $\mathrm{CAC} 40$ & 16.08.2005 \\
\hline Germany & $\begin{array}{l}\text { Bayerische Landesbank, Commerzbank, } \\
\text { Deutsche Bank, HSH Nordbank, IKB } \\
\text { Deutsche Industriebank, LB } \\
\text { Badenwürttemberg, LB Hessen-Thüringen, } \\
\text { Nord-LB, Portigon }\end{array}$ & $\begin{array}{l}\text { BASF, Bayer, Deutsche Post, E.ON, HeidelbergCement, } \\
\text { Henkel, Linde, REW, Thyssen Krupp, Volkswagen }\end{array}$ & Interbank & DAX 30 & 09.02.2004 \\
\hline Greece & Alpha Bank & Hellenic Telecom & Interbank & $\begin{array}{l}\text { ATHEX } \\
\text { COMPOSITE }\end{array}$ & 09.01 .2004 \\
\hline Ireland & $\begin{array}{l}\text { Allied Irish BanksThe Governor and } \\
\text { Company, Permanet SB Public }\end{array}$ & Smurfit Kappa & Interbank & $\begin{array}{l}\text { IRELAND SE } \\
\text { OVERALL (ISEQ) }\end{array}$ & 24.10 .2006 \\
\hline Italy & $\begin{array}{l}\text { Banca Monte dei Paschi di Siena, Banco } \\
\text { Popolare, Banca Popolare di Milano Soco, } \\
\text { BNL, Mediobanca, Unicredito Italiano, } \\
\text { Unione die Banche, Intesa Sanpaolo }\end{array}$ & Enel, Eni, Fiat, Finmeccanica, Telekom Italia & Interbank & FTSE MIB INDEX & 02.03 .2004 \\
\hline
\end{tabular}


Netherlands

Cooptieve Cente Rabobank, SNS Bank, Fortis Bank, ING Bank

Portugal

Banco Commercial Portugues, Banco Espirito Santo, Caixa Geral de Diposits

Spain
Banco Popular Espanol, Bankinter, BBV Argentaria, Banco Santander
Aegon, Akzo Nobel, Heineken, Koninklijke Philips,

Unilever, Wolters Kluwer, Eneco Holding, Essent,

Koninklijke Ahold, Koninklijke DSM, Koninklijke KPN

EDP - Energias de Portugal, Portugal Telekom, Brisa Auto-Estradas de Portugal

Endesa, Gas Natural, Iberdrola, Repsol, Telefonica
Interbank

AEX

23.10 .2006

PSI-20

23.11.2005

Interbank

IBEX 35

\section{Exogenous variables}

All for sample period 06.01.2004-31.07.2013

Money market spread

ECB non-standard measures
3 Month Euribor - 3M OIS spread

Announcement dummies for LTROs between 6 and 12 months (28 Mar., 4 Sep., and 15 Oct. 2008; 7 May 2009; 4 Aug. and 6 Oct. 2011), Allotted amounts in LTROs (in bn. Euro)

Announcement dummy for LTROs between 12 and 36 months (8 Dec. 2011), Allotted amounts in LTROs (in bn. Euro, equally split over three days before and on day after the auction)

SMP announcement dummies (10 May 2010, 8 Aug. 2011), Change in SMP holdings (Euro bn., split over the week)

OMT announcement dummies (26 Jul. and 6 Sep. 2012)

Bailout announcements

CGFS, \& BIS (2010, October 27). Financial sector rescue plan database, maintained by the BIS, under the auspices of the Committee on the Global Financial System

Vdax New

Implied volatility

Macroeconomic news

European Commission Manufacturing Confidence, Eurozone Industrial Confidence, European Commission Economic Sentiment Indicator, ZEW Germany Expectation of Economic Growth, Germany Industrial Production MoM SA, Italy Business Confidence, France Households Consumption Goods Expenditure Total MoM, Bank of France Business Sentiment Indicator, Germany Manufacturing Orders MoM SA, Germany Retail Sales Const.2005 Prices YoY NSA, Germany GDP Chain Linked Pan German QoQ, USA GDP YoY
Notes:
* 3 month; long rate is always yield on 10 year benchmark government bond
** total return indices
*** sample end is always 31.07.2013, except for Greece (ends on 23.02.2012)

Source:

All financial market data are downloaded from Datastream and Bloomberg; Data on ECB measures are downloaded from the ECB's website. 